\title{
Molecular phylogenetic analysis reveals seven new Diaporthe species from Italy
}

\author{
Dissanayake AJ ${ }^{1,2}$, Camporesi $\mathrm{E}^{3}$, Hyde $\mathrm{KD}^{2}$, Zhang $\mathrm{Wei}^{1}$, Yan JY ${ }^{1}$ and Li XH ${ }^{{ }^{*}}$ \\ ${ }^{1}$ Beijing Key Laboratory of Environmental Friendly Management on Fruit diseases and Pests in North China, Institute of \\ Plant and Environment Protection, Beijing Academy of Agriculture and Forestry Sciences, Beijing 100097, People's \\ Republic of China \\ ${ }^{2}$ Center of Excellence in Fungal Research, School of Science, Mae Fah Luang University, Chiang Rai 57100, Thailand \\ ${ }^{3}$ A.M.B. Gruppo Micologico Forlivese "Antonio Cicognani”, Via Roma 18, Forli, Italy
}

Dissanayake AJ, Camporesi E, Hyde KD, Zhang Wei, Yan JY, Li XH 2017 - Molecular phylogenetic analysis reveals seven new Diaporthe species from Italy. Mycosphere 8(5), 853-877, Doi $10.5943 /$ mycosphere/8/5/4

\begin{abstract}
Seven new species of Diaporthe, D. acericola on Acer negundo, D. cichorii on Cichorium intybus, D. dorycnii on Dorycnium hirsutum, D. lonicerae on Lonicera sp., Laurus nobilis and Torilis arvensis, D. pseudotsugae on Pseudotsuga menziesii, D. schoeni on Schoenus nigricans, Carduus sp. and Plantago sp. and D. torilicola on Torilis arvensis from Italy are described and illustrated based on morphological characteristics and molecular analyses. In addition to the new species, eight known species of Diaporthe, D. eres, D. foeniculina, D. gulyae, D. novem, D. ravennica, D. rhusicola, D. rudis and D. sterilis were identified. Phylogenetic relationships of the new species with other Diaporthe species were revealed by DNA sequence analyses based on the internal transcribed spacer (ITS) region, translation elongation factor 1-alpha (TEF), partial regions of the $\beta$-tubulin (BT) and calmodulin (CAL). Among 44 isolates, D. eres was the dominant species, accounting for $27 \%$ of the frequency of occurrence. Our study revealed a high diversity of undescribed Diaporthe species from various hosts in Italy.
\end{abstract}

Key words - Diaporthales - Hosts - Morphology - Sordariomycetes - Taxonomy

\section{Introduction}

Diaporthe (including the Phomopsis asexual morph) belongs to family Diaporthaceae, order Diaporthales, and class Sordariomycetes (Hyde et al. 2014, Maharachchikumbura et al. 2015, 2016) and its species are found worldwide on a diverse range of host plants as endophytes, pathogens and saprobes (Gomes et al. 2013). Many Diaporthe species that are morphologically similar have proven to be genetically distinct (van Rensburg et al. 2006), and several isolates that were formerly identified based on their host, were shown to represent different taxa (Hyde et al. 2014). Diaporthe represents a highly complex genus containing numerous cryptic species. In recent studies, species of Diaporthe were distinguished mainly by their molecular phylogenies, and the best five gene regions to conduct a multigene phylogenetic analysis are ITS, TEF, ACT CAL and HIS (van Rensburg et al. 2006, Santos et al. 
2010, Udayanga et al. 2011, 2012, Gomes et al. 2013). Although ex-type/ex-epitype/ex-isotype/exneotype strains are available for 150 species of Diaporthe (Dissanayake et al. 2017b), only 13 have been reported associated with hosts in Italy (Table 1). During the last three years, a collection of Diaporthe isolates was obtained from branches and stems of various woody hosts in Arezzo, Forlì-Cesena and Ravenna Provinces in Italy. The aim of this study was to identify the species and reveal the distribution of species on the hosts. Isolates were characterized in terms of morphology and their phylogenetic position within Diaporthe.

Table 1 Diaporthe species associated with hosts in Italy

\begin{tabular}{|c|c|c|}
\hline Species & Disease symptoms \& hosts & References \\
\hline Diaporthe alnea & Dieback of Alnus glutinosa & Moricca 2002 \\
\hline D. ambigua & Dieback of Platanus acerifolia & Gomes et al. 2013 \\
\hline D. eres & Cane blight of Vitis vinifera & Cinelli et al. 2016 \\
\hline D. foeniculina & $\begin{array}{l}\text { Decline and mortality of Eucalyptus camaldulensis } \\
\text { Stem and shoot cankers on Castanea sativa } \\
\text { Branch cankers and stem-end rot of Persea americana }\end{array}$ & $\begin{array}{l}\text { Deidda et al. } 2016 \\
\text { Annesi et al. } 2016 \\
\text { Guarnaccia et al. } 2016\end{array}$ \\
\hline D. helianthi & Stem canker of Helianthus annuus & Pecchia et al. 2004 \\
\hline D. melonis & Black rot of Cucumis melo & Bertetti et al. 2011 \\
\hline D. ravennica & Tamarix sp. & Thambugala et al. 2017 \\
\hline D. sclerotioides & Black root rot of Cucumis sativus & Cappelli et al. 2004 \\
\hline Phomopsis endogena & Brown rot on nuts of Castanea sativa & Maresi et al. 2013 \\
\hline \multirow[t]{2}{*}{ P. quercina } & Endophyte in Quercus sp. & Ragazzi et al. 2003 \\
\hline & Endophyte in Quercus robur & Gonthier et al. 2006 \\
\hline \multirow[t]{3}{*}{ Phomopsis sp. } & Dieback of Pinus nigra seedlings & Nicosia et al. 2015 \\
\hline & Post-harvest fruit rot of Actinidia sp. & Luongo et al. 2011 \\
\hline & Symptomatic twigs of Olea europaea & Frisullo et al. 2015 \\
\hline
\end{tabular}

\section{Materials \& methods}

\section{Sample collection, specimen examination and isolations}

During 2014 to 2016, 44 isolates were collected from woody branches and stems of 42 hosts belonging to 26 host families (Adoxaceae, Apiaceae, Asteraceae, Betulaceae, Brassicaceae, Caprifoliaceae, Caprifoliaceae, Cornaceae, Cupressaceae, Cyperaceae, Dioscoreaceae, Fabaceae, Hemerocallidoideae, Juglandaceae, Lamiaceae, Lauraceae, Pinaceae, Plantaginaceae, Platanaceae, Poaceae, Rhamnaceae, Rosaceae, Rubiaceae, Salicaceae, Sapindaceae, Simaroubaceae) from three provinces of Italy: Arezzo, Forlì-Cesena and Ravenna (Fig. 1). Specimens were observed and examined with a Motic SMZ 168 stereomicroscope. Micro-morphological characters were determined with a Nikon ECLIPSE 80i compound microscope and images were captured with a Canon EOS 550D digital camera. Observations and photographs were made from materials mounted in water. Measurements were made with the Tarosoft (R) Image Frame Work and images used for figures were processed with Adobe Photoshop CS3 Extended version 10.0. Single spore isolations were prepared following the method of Chomnunti et al. (2014). Spore germination on water agar (WA) was examined after $24 \mathrm{~h}$ and germinating spores were transferred to potato dextrose agar (PDA) media. Cultures were incubated at $18^{\circ} \mathrm{C}$ in the dark and colony color was examined according to Rayner (1970) after $15 \mathrm{~d}$ of growth on PDA at $25{ }^{\circ} \mathrm{C}$ in the dark. Herbarium specimens are deposited in Mae Fah Luang University Herbarium (MFLU) while, ex-type living cultures are deposited at the Mae Fah Luang University Culture Collection (MFLUCC) in Thailand (Table 2). 
Table 2 Diaporthe species studied in this study (Fig. 2). Details of ex-type species introduced in this study are in bold.

\begin{tabular}{|c|c|c|c|c|c|c|c|c|c|c|}
\hline \multirow[t]{2}{*}{ Species } & \multirow[t]{2}{*}{ Strain } & \multirow[t]{2}{*}{ Host } & \multirow[t]{2}{*}{ Habit } & \multirow[t]{2}{*}{ Locality } & \multirow[t]{2}{*}{ Collector } & \multirow[t]{2}{*}{ Colle. date } & \multicolumn{4}{|c|}{ GenBank Accession numbers } \\
\hline & & & & & & & ITS & TEF & BT & CAL \\
\hline D. acericola & MFLUCC 17-0956 & Acer negundo (Sapindaceae) & Dead branch, samaras & Forlì-Cesena, Italy & E. Camporesi & 22.01 .2015 & KY964224 & KY964180 & KY964074 & KY964137 \\
\hline D. cichorii & MFLUCC 17-1023 & Cichorium intybus (Asteraceae) & Dead aerial stem & Forlì-Cesena, Italy & E. Camporesi & 17.07.2016 & KY964220 & KY964176 & KY964104 & KY964133 \\
\hline D. dorycnii & MFLUCC 17-1015 & Dorycnium hirsutum (Fabaceae) & Dead aerial stem & Forlì-Cesena, Italy & E. Camporesi & 02.05.2016 & KY964215 & KY964171 & KY964099 & No \\
\hline D. eres & MFLUCC 17-0957 & Sambucus nigra (Adoxaceae) & Dead aerial branch & Forlì-Cesena, Italy & E. Camporesi & 07.02 .2015 & KY964187 & KY964143 & KY964070 & KY964114 \\
\hline D. eres & MFLUCC 17-0965 & Lonicera sp. (Caprifoliaceae) & Dead aerial branch & Forlì-Cesena, Italy & E. Camporesi & 28.02 .2015 & KY964189 & KY964145 & KY964072 & KY964115 \\
\hline D. eres & MFLUCC 17-0964 & Sonchus oleraceus (Asteraceae) & Dead aerial stem & Forlì-Cesena, Italy & E. Camporesi & 06.05 .2015 & KY964192 & KY964148 & KY964076 & KY964117 \\
\hline D. eres & MFLUCC 17-0971 & Salix caprea (Salicaceae) & Dead aerial branch & Arezzo, Italy & E. Camporesi & 19.06.2015 & KY964194 & KY964150 & KY964078 & KY964119 \\
\hline D. eres & MFLUCC 17-0993 & Picea excels (Pinaceae) & Dead land cone & Forlì-Cesena, Italy & E. Camporesi & 18.01 .2016 & KY964200 & KY964156 & KY964084 & KY964123 \\
\hline D. eres & MFLUCC 17-0997 & Juglans regia (Juglandaceae) & Dead land branch & Forlì-Cesena, Italy & E. Camporesi & 22.02 .2016 & KY964202 & KY964158 & KY964086 & KY964124 \\
\hline D. eres & MFLUCC 17-0999 & Populus nigra (Salicaceae) & Dead aerial branch & Forlì-Cesena, Italy & - & - & KY964203 & KY964159 & KY964087 & KY964125 \\
\hline D. eres & MFLUCC 17-1012 & Sanguisorba minor (Rosaceae) & Dead aerial stem & Forlì-Cesena, Italy & E. Camporesi & 11.04 .2016 & KY964213 & KY964169 & KY964097 & KY964128 \\
\hline D. eres & MFLUCC 17-1016 & Pinus pinaster (Pinaceae) & Dead land cone & Forlì-Cesena, Italy & E. Camporesi & 03.05 .2016 & KY964216 & KY964172 & KY964100 & KY964129 \\
\hline D. eres & MFLUCC $17-1017$ & Ostrya carpinifolia (Betulaceae) & Dead aerial branch & Forlì-Cesena, Italy & E. Camporesi & 07.05 .2016 & KY964217 & KY964173 & KY964101 & KY964130 \\
\hline D. eres & MFLUCC 17-1021 & Galega officinalis (Fabaceae) & Dead aerial stem & Arezzo, Italy & E. Camporesi & 07.07.2016 & KY964219 & KY964175 & KY964103 & KY964132 \\
\hline D. eres & MFLUCC 17-1025 & Rhamnus alpinus (Rhamnaceae) & Dead aerial branch & Forlì-Cesena, Italy & E. Camporesi & 14.08.2016 & KY964221 & KY964177 & KY964105 & KY964134 \\
\hline D. foeniculina & MFLUCC 17-1068 & Ailanthus altissima (Simaroubaceae) & Dead land stem-leaf & Forlì-Cesena, Italy & E. Camporesi & 07.02 .2015 & KY964188 & KY964144 & KY964071 & - \\
\hline D. foeniculina & MFLUCC 17-0974 & Melilotus officinalis (Fabaceae) & Dead aerial stem & Forlì-Cesena, Italy & E. Camporesi & 07.09 .2015 & KY964196 & KY964152 & KY964080 & - \\
\hline D. foeniculina & MFLUCC 17-0995 & Hemerocallis fulva (Hemerocallidoideae) & Dead aerial stem & Forlì-Cesena, Italy & E. Camporesi & 10.02 .2016 & KY964201 & KY964157 & KY964085 & - \\
\hline D. foeniculina & MFLUCC 17-1003 & Achillea millefolium (Asteraceae) & Dead aerial stem & Forlì-Cesena, Italy & E. Camporesi & 16.03.2016 & KY964205 & KY964161 & KY964089 & - \\
\hline D. foeniculina & MFLUCC 17-1005 & Arctium minus (Asteraceae) & Dead aerial stem & Forlì-Cesena, Italy & E. Camporesi & 08.03 .2016 & KY964207 & KY964163 & KY964091 & - \\
\hline D. foeniculina & MFLUCC 17-1006 & Wisteria sinensis (Fabaceae) & Dead aerial stems & Forlì-Cesena, Italy & E. Camporesi & 09.03.2016 & KY964208 & KY964164 & KY964092 & - \\
\hline D. foeniculina & MFLUCC 17-1008 & Lunaria rediviva (Brassicaceae) & Dead aerial stem & Forlì-Cesena, Italy & E. Camporesi & 16.03.2016 & KY964209 & KY964165 & KY964093 & - \\
\hline D. foeniculina & MFLUCC 17-1009 & Cupressus sepervirens (Cupressaceae) & Dead land cone & Forlì-Cesena, Italy & E. Camporesi & 21.03 .2016 & KY964210 & KY964166 & KY964094 & - \\
\hline D. foeniculina & MFLUCC $17-1020$ & Vicia sp. (Fabaceae) & Dead aerial stem & Arezzo, Italy & E. Camporesi & 19.06 .2016 & KY964218 & KY964174 & KY964102 & KY964131 \\
\hline D. gulyae & MFLUCC 17-1026 & Heracleum sphondylium (Apiaceae) & Dead aerial stem & Forlì-Cesena, Italy & E. Camporesi & 28.08 .2016 & KY964223 & KY964179 & KY964107 & KY964136 \\
\hline D. lonicerae & MFLUCC 17-0963 & Lonicera sp. (Caprifoliaceae) & Dead aerial branch & Forlì-Cesena, Italy & E. Camporesi & 28.02.2015 & KY964190 & KY964146 & KY964073 & KY964116 \\
\hline D. lonicerae & MFLUCC 17-0976 & Laurus nobilis (Lauraceae) & Dead aerial branch & Forlì-Cesena, Italy & E. Camporesi & 15.09 .2015 & KY964197 & KY964153 & KY964081 & KY964121 \\
\hline D. lonicerae & MFLUCC 17-0978 & Torilis arvensis (Apiaceae) & Dead aerial stem & Forlì-Cesena, Italy & E. Camporesi & 23.09.2015 & KY964198 & KY964154 & KY964082 & KY964122 \\
\hline D. novem & MFLUCC 17-1028 & Galium sp. (Rubiaceae) & Dead aerial stem & Arezzo, Italy & E. Camporesi & 19.06.2015 & KY964195 & KY964151 & KY964079 & KY964120 \\
\hline D. pseudotsugae & MFLU 15-3228 & Pseudotsuga menziesii (Pinaceae) & Dead land cones & Forlì-Cesena, Italy & E. Camporesi & 10.04.2015 & KY964225 & KY964181 & KY964108 & KY964138 \\
\hline D. ravennica & MFLUCC 17-1029 & Salvia sp. (Lamiaceae) & Dead aerial stem & Forlì-Cesena, Italy & E. Camporesi & 21.04 .2015 & KY964191 & KY964147 & KY964075 & - \\
\hline D. rhusicola & MFLUCC 17-0987 & Amorpha fruticosa (Fabaceae) & Dead aerial branch & Forlì-Cesena, Italy & E. Camporesi & 17.11 .2015 & KY964199 & KY964155 & KY964083 & - \\
\hline D. rhusicola & MFLUCC 17-1001 & Angelica sylvestris (Apiaceae) & Dead aerial stem & Forlì-Cesena, Italy & E. Camporesi & 29.02.2016 & KY964204 & KY964160 & KY964088 & - \\
\hline D. rhusicola & MFLUCC 17-1004 & Rubus sp. (Rosaceae) & Dead aerial branch & Forlì-Cesena, Italy & E. Camporesi & 14.03 .2016 & KY964206 & KY964162 & KY964090 & - \\
\hline D. rhusicola & MFLUCC 17-1014 & Platanus hybrida (Platanaceae) & Dead aerial branch & Forlì-Cesena, Italy & E. Camporesi & 27.04 .2016 & KY964214 & KY964170 & KY964098 & - \\
\hline D. rudis & MFLUCC 17-1030 & Cornus sp. (Cornaceae) & Dead aerial branch & Forlì-Cesena, Italy & E. Camporesi & 10.11 .2014 & KY964186 & KY964142 & KY964069 & KY964113 \\
\hline D. rudis & MFLU 15-1264 & Anthoxanthum odoratum (Poaceae) & Dead aerial stem & Forlì-Cesena, Italy & E. Camporesi & 21.05 .2015 & KY964227 & KY964183 & KY964110 & KY964140 \\
\hline D. rudis & MFLUCC 17-0969 & Carlina vulgaris (Asteraceae) & Dead aerial stem & Forlì-Cesena, Italy & E. Camporesi & 22.04 .2015 & KY964193 & KY964149 & KY964077 & KY964118 \\
\hline D. rudis & MFLUCC 17-1073 & Dioscorea communis (Dioscoreaceae) & Dead aerial stem & Forlì-Cesena, Italy & E. Camporesi & 28.08.2016 & KY964222 & KY964178 & KY964106 & KY964135 \\
\hline D. schoeni & MFLU 15-1279 & Schoenus nigricans (Cyperaceae) & Dead aerial stem & Ravenna, Italy & E. Camporesi & 01.05.2015 & KY964226 & KY964182 & KY964109 & KY964139 \\
\hline D. schoeni & MFLU 15-2266 & Carduus sp. (Asteraceae) & Dead aerial stem & Arezzo, Italy & E. Camporesi & 26.06.2015 & KY964228 & KY964184 & KY964111 & - \\
\hline D. schoeni & MFLU 15-2609 & Plantago sp. (Plantaginaceae) & Dead aerial stem & Forlì-Cesena, Italy & E. Camporesi & 25.08 .2015 & KY964229 & KY964185 & KY964112 & KY964141 \\
\hline D. sterilis & MFLUCC 17-1011 & Cytisus sp. (Fabaceae) & Dead aerial branch & Forlì-Cesena, Italy & E. Camporesi & 04.04 .2016 & KY964211 & KY964167 & KY964095 & KY964126 \\
\hline D. torilicola & MFLUCC 17-1051 & Torilis arvensis (Apiaceae) & Dead aerial stem & Forlì-Cesena, Italy & E. Camporesi & 21.04.2016 & KY964212 & KY964168 & KY964096 & KY964127 \\
\hline
\end{tabular}


Table 3 Isolates from GenBank used in phylogenetic analyses (Fig. 2). Ex-type isolates are in bold.

\begin{tabular}{|c|c|c|c|c|c|c|}
\hline Species & Isolate & Host & ITS & BT & TEF & CAL \\
\hline D. acaciigena & CBS 129521 & Acacia retinodes & KC343005 & KC343973 & KC343731 & KC343247 \\
\hline D. alleghaniensis & CBS 495.72 & Betula alleghaniensis & KC343007 & KC343975 & KC343733 & КC343249 \\
\hline \multirow[t]{2}{*}{ D. alnea } & CBS 146.46 & Alnus sp. & KC343008 & KC343976 & KC343734 & KC343250 \\
\hline & CBS 159.47 & Alnus sp. & KC343009 & KC343977 & KC343735 & KC343251 \\
\hline \multirow[t]{2}{*}{ D. ampelina } & CBS 114016 & Vitis vinifera & $\mathrm{AF} 230751$ & JX275452 & AY745056 & AY230751 \\
\hline & CBS 267.80 & Vitis vinifera & KC343018 & KC343986 & KC343744 & KC343260 \\
\hline \multirow[t]{2}{*}{ D. amygdali } & CBS 126679 & Prunus dulcis & KC343022 & KC343990 & AY343748 & KC343264 \\
\hline & CBS 111811 & Vitis vinifera & KC343019 & KC343987 & KC 343745 & KC343261 \\
\hline D. arctii & DP0482 & Arctium lappa & KJ590736 & KJ610891 & KJ590776 & KJ612133 \\
\hline \multirow[t]{2}{*}{ D. asheicola } & CBS 136967 & Vaccinium ashei & KJ160562 & KJ160518 & KJ160594 & KJ160542 \\
\hline & CBS 136968 & Vaccinium ashei & KJ160563 & KJ160519 & KJ160595 & KJ160543 \\
\hline \multirow[t]{2}{*}{ D. australafricana } & CBS 111886 & Vitis vinifera & KC343038 & KC344006 & KC343764 & KC343280 \\
\hline & CBS 113487 & Vitis vinifera & KC343039 & KC344007 & KC343765 & KC343281 \\
\hline \multirow[t]{2}{*}{ D. baccae } & CBS 136972 & Vaccinium corymbosum & KJ160565 & No & KJ160597 & No \\
\hline & CPC 20585 & Vaccinium corymbosum & KJ160564 & No & KJ160596 & No \\
\hline \multirow[t]{2}{*}{ D. betulae } & CFCC 50469 & Betula platyphylla & KT732950 & KT733020 & KT733016 & KT732997 \\
\hline & CFCC 50470 & Betula platyphylla & KT732951 & KT733021 & KT733017 & KT732998 \\
\hline D. bicincta & CBS 121004 & Juglans sp. & KC343134 & KC344102 & KC343860 & КC343376 \\
\hline \multirow[t]{2}{*}{ D. biguttusis } & CGMCC 3.17081 & Lithocarpus glabra & KF576282 & KF576306 & KF576257 & No \\
\hline & CGMCC 3.17082 & Lithocarpus glabra & KF576283 & KF576307 & KF576258 & No \\
\hline D. canthii & CBS 132533 & Canthium inerme & JX069864 & KC843230 & KC843120 & KC843174 \\
\hline D. cassines & CPC 21916 & Cassine peragua & KF777155 & No & KF777244 & No \\
\hline D. celastrina & CBS 139.27 & Celastrus scandens & KC343047 & KC344015 & KC343773 & KC343289 \\
\hline \multirow[t]{2}{*}{ D. chamaeropis } & CBS 454.81 & Chamaerops humilis & KC343048 & KC344016 & KC 343774 & КC343290 \\
\hline & CBS 753.70 & Spartium junceum & KC343049 & KC344017 & KC343775 & КC343291 \\
\hline \multirow[t]{2}{*}{ D. cucurbitae } & DAOM42078 & Cucumis sativus & KM453210 & KP118848 & $\begin{array}{l}\text { KM45321 } \\
1\end{array}$ & No \\
\hline & CBS 136.25 & Arctium sp. & KC343031 & KC343999 & KC343757 & KC343273 \\
\hline D. cynaroidis & CBS 122676 & Protea cynaroides & KC343058 & KC344026 & KC343784 & KC343300 \\
\hline \multirow[t]{2}{*}{ D. cytosporella } & FAU461 & Citrus limon & KC843307 & KC843221 & KC843116 & KC843141 \\
\hline & AR5149 & Citrus sinensis & KC843309 & KC843222 & KC843118 & KC843287 \\
\hline D. diospyricola & CPC 21169 & Diospyros whyteana & KF777156 & No & No & No \\
\hline \multirow[t]{2}{*}{ D. ellipicola } & CGMCC 3.17084 & Lithocarpus glabra & KF576270 & KF576291 & KF576245 & No \\
\hline & CGMCC 3.17085 & Lithocarpus glabra & KF576271 & KF576292 & KF576246 & No \\
\hline \multirow[t]{5}{*}{ D. eres } & AR519 & Ulmus sp. & KJ210529 & KJ420799 & $\mathrm{KJ} 210550$ & KJ434999 \\
\hline & CBS 138598 & Ulmus sp. & $\mathrm{KJ} 210521$ & KJ420787 & $\mathrm{KJ} 210545$ & KJ435027 \\
\hline & CBS 439.82 & Cotoneaster sp. & FJ889450 & JX275437 & GQ250341 & JX197429 \\
\hline & DLR12A & Vitis vinifera & $\mathrm{KJ} 210518$ & KJ420783 & KJ210542 & KJ434996 \\
\hline & CBS 587.79 & Pinus pantepella & KC343153 & KC344121 & KC343879 & KC343395 \\
\hline
\end{tabular}




\begin{tabular}{|c|c|c|c|c|c|c|}
\hline \multirow[t]{6}{*}{ D. foeniculina } & CBS 111553 & Foeniculum vulgare & KC343101 & КC344069 & KC343827 & KC343343 \\
\hline & FAU460 & Citrus limon & KC843304 & KC843218 & KC843113 & KC843138 \\
\hline & ICMP 12285 & Juglans regia & KC145853 & No & KC145937 & No \\
\hline & AR5151 & Citrus latifolia & KC843303 & KC843217 & KC843112 & KC843137 \\
\hline & CBS 187.27 & Camellia sinesis & DQ286287 & JX275463 & DQ286261 & KC843122 \\
\hline & CBS 123208 & Foeniculum valgare & EU814480 & JX275464 & GQ250315 & KC843125 \\
\hline \multirow[t]{2}{*}{ D. fusicola } & CGMCC 3.17087 & Lithocarpus glabra & KF576281 & KF576305 & KF576256 & KF576233 \\
\hline & CGMCC 3.17088 & Lithocarpus glabra & KF576263 & KF576287 & KF576238 & No \\
\hline D. garethjonesii & $\begin{array}{l}\text { MFLUCC 12- } \\
\text { 0542a }\end{array}$ & Unknown dead leaf & KT459423 & KT459441 & KT459457 & KT459470 \\
\hline \multirow{2}{*}{ D. gulyae } & BRIP 54025 & Helianthus annuus & JF431299 & No & JN645803 & No \\
\hline & BRIP 53158 & Helianthus annuиs & JF431284 & No & JN645799 & No \\
\hline D. helicis & AR5211 & Hedera helix & KJ210538 & KJ420828 & KJ210559 & KJ435043 \\
\hline D. hickoriae & CBS 145.26 & Carya glabra & KC343118 & KC344086 & KC343844 & KC 343360 \\
\hline \multirow{2}{*}{ D. longicicola } & CGMCC 3.17089 & Lithocarpus glabra & KF576267 & KF576291 & KF576242 & No \\
\hline & CGMCC 3.17090 & Lithocarpus glabra & KF576268 & KF576292 & KF576243 & No \\
\hline \multirow[t]{2}{*}{ D. mahothocarpus } & CGMCC 3.15181 & Lithocarpus glabra & KC153096 & KF576312 & KC153087 & No \\
\hline & CGMCC 3.15182 & Lithocarpus glabra & KC153097 & No & KC153088 & No \\
\hline D. maritima & DAOMC 250563 & Picea rubens & No & KU574616 & No & No \\
\hline D. neilliae & CBS 144. 27 & Spiraea sp. & KC343144 & KC344112 & KC343870 & KC343386 \\
\hline D. neoarctii & CBS 109490 & Ambrosia trifida & KC343145 & KC344113 & KC343871 & KC343387 \\
\hline D. nothofagi & BRIP 54801 & $\begin{array}{l}\text { Nothofagus } \\
\text { cunninghamii }\end{array}$ & JX862530 & KF170922 & JX862536 & No \\
\hline \multirow[t]{2}{*}{ D. novem } & CBS 127270 & Glycine max & KC343155 & KC344123 & KC343881 & KC343397 \\
\hline & CBS 127271 & Glycine $\max$ & KC343157 & KC344125 & KC343883 & KC343399 \\
\hline \multirow[t]{2}{*}{ D. ovoicicola } & CGMCC 3.17093 & Citrus sp. & KF576265 & KF576289 & KF576240 & KF576223 \\
\hline & CGMCC 3.17092 & Citrus sp. & KF576264 & KF576288 & KF576239 & KF576222 \\
\hline D. penetriteum & CGMCC 3.17532 & Camellia sinensis & KP267879 & KP293459 & KP267953 & No \\
\hline D. phaseolorum & AR4203 & Phaseolus vulgaris & KJ590738 & KJ610893 & KJ590739 & KJ612135 \\
\hline D. phragmitis & CBS 138897 & Phragmites australis & KP004445 & KP004507 & No & No \\
\hline D. pulla & CBS 338.89 & Hedera helix & KC343152 & KC344120 & KC343878 & KC343394 \\
\hline \multirow[t]{2}{*}{ D. ravennica } & $\begin{array}{l}\text { MFLUCC 15- } \\
0479\end{array}$ & Tamarix sp. & KU900335 & KX432254 & KX365197 & No \\
\hline & $\begin{array}{l}\text { MFLUCC 15- } \\
0480\end{array}$ & Tamarix sp. & KU900336 & KX377688 & KX426703 & No \\
\hline D. rhusicola & CBS 129528 & Rhus pendulina & JF951146 & No & No & No \\
\hline \multirow[t]{5}{*}{ D. rudis } & AR3422 & Laburnum anagyroides & KC843331 & KC843177 & KC843090 & KC843146 \\
\hline & AR3654 & Rosa canina & KC843338 & KC843184 & KC843097 & KC843153 \\
\hline & ICMP 16419 & Castanea sativa & KC145904 & No & KC145976 & No \\
\hline & DA244 & Brugmansia sp. & KC843334 & KC843180 & KC843093 & KC843149 \\
\hline & CBS 113201 & Vitis vinifera & AY485750 & JX275454 & GQ250327 & JX197445 \\
\hline
\end{tabular}




\begin{tabular}{|c|c|c|c|c|c|c|}
\hline D. saccarata & CBS 116311 & Protearepens & KC343190 & KC344158 & KC343916 & KC343432 \\
\hline D. salicicola & BRIP 54825 & Salix purpurea & JX862531 & JX862531 & JX862537 & No \\
\hline \multirow[t]{6}{*}{ D. sojae } & FAU635 & Glycine $\max$ & KJ590719 & KJ610875 & KJ590762 & KJ612116 \\
\hline & CBS 116019 & Caperonia palustris & KC343175 & KC344143 & KC343901 & KC343417 \\
\hline & FAU455 & Stokesia laevis & KJ590712 & KJ610868 & KJ590755 & KJ612109 \\
\hline & DP0601 & Glycine $\max$ & KJ590706 & KJ610862 & KJ590749 & KJ612103 \\
\hline & MAFF 410444 & Cucumis melo & KJ590714 & KJ610870 & KJ590757 & KJ612111 \\
\hline & BRIP 54033 & Helianthus annuus & JF431295 & No & JN645809 & No \\
\hline D. spartinicola & CBS 140003 & Spartium junceum & KR611879 & No & No & No \\
\hline \multirow[t]{2}{*}{ D. sterilis } & CBS 136969 & Vaccinium corymbosum & KJ160579 & KJ160528 & KJ160611 & KJ160548 \\
\hline & CPC 20580 & Vaccinium corymbosum & KJ160582 & KJ160531 & KJ160614 & KJ160551 \\
\hline \multirow[t]{2}{*}{ D. subclavata } & ZJUD95 & Citrus sp. & KJ490630 & KJ490451 & KJ490509 & No \\
\hline & CGMCC 3.17253 & Citrus grandis & KJ490618 & KJ490439 & KJ490497 & No \\
\hline \multirow[t]{2}{*}{ D. ternstroemia } & CGMCC 3.15183 & $\begin{array}{l}\text { Ternstroemia } \\
\text { gymnanthera }\end{array}$ & KC153098 & No & KC153089 & No \\
\hline & CGMCC 3.15184 & $\begin{array}{l}\text { Ternstroemia } \\
\text { gymnanthera }\end{array}$ & KC153099 & No & KC153090 & No \\
\hline \multirow[t]{2}{*}{ D. toxica } & CBS 534.93 & Lupinus angustifolius & KC343220 & KC344188 & KC343946 & KC343462 \\
\hline & CBS 546.93 & Lupinus sp. & KC343222 & KC344190 & KC343948 & KC343464 \\
\hline \multirow[t]{3}{*}{ D. vaccinii } & CBS 160.32 & Vaccinium macrocarpon & AF317578 & JX270436 & GQ250326 & KC343470 \\
\hline & CBS 122116 & Vaccinium corymbosum & KC343227 & KC344195 & KC 343953 & KC343469 \\
\hline & CBS 135436 & Vaccinium corymbosum & AF317570 & KC843225 & JQ807380 & KC849456 \\
\hline D. virgiliae & CMW40748 & Virgilia oroboides & KP247566 & KP247575 & No & No \\
\hline $\begin{array}{l}\text { Diaporthella } \\
\text { corylina }\end{array}$ & CBS 121124 & Corylus sp. & KC343004 & KC343972 & KC343730 & KC343246 \\
\hline
\end{tabular}

\section{Molecular based amplification}

Total DNA was extracted from aerial mycelium of 7 day old cultures grown on PDA at $25 \mathrm{C}$ following the modified cetyltrimethyl ammonium bromide (CTAB) method described by Udayanga et al. (2012). Under circumstances where fungi failed to grow in culture, DNA was extracted directly from fruiting bodies using aseptic techniques. For the identification of Diaporthe, rDNA internal transcribed spacer (ITS) region was amplified and sequenced for all 44 isolates. The translation elongation factor 1- $\alpha$ (TEF), a portion of the $\beta$-tubulin (BT) gene and the calmodulin (CAL) gene were employed to support species identification based on ITS gene sequence data. The rDNA ITS region was amplified using universal primers ITS1 and ITS4 (White et al. 1990). The target region of the TEF gene was amplified using primer pairs EF-728F and EF-986R (Carbone \& Kohn 1999). A portion of the BT gene was amplified using the primers BT2a and BT2b (Glass \& Donaldson 1995), while the primer pair CAL228F and CAL737R (Carbone \& Kohn 1999) was used to amplify the CAL. The PCR reactions were performed in a BIORAD $1000^{\mathrm{TM}}$ thermal cycler in a total volume of $25 \mu \mathrm{l}$. The PCR mixture contained TaKaRa Ex-Taq DNA polymerase $0.3 \mu \mathrm{l}, 12.5 \mu \mathrm{l}$ of $2 \times$ PCR buffer with $2.5 \mu \mathrm{l}$ of dNTPs, $1 \mu \mathrm{l}$ of each primer, 9.2 $\mu \mathrm{l}$ of double-distilled water and 100-500 ng of DNA template. DNA samples were detected by electrophoresis and ethidium bromide (EB) staining and were used as templates for PCR amplification. DNA sequencing was performed by Sunbiotech Company, Beijing, China. 


\section{Sequence alignment and phylogenetic analyses}

All new sequences generated in this study were checked manually and nucleotides at ambiguous positions were clarified with sequences from both strands and aligned with sequences retrieved from GenBank based on recent publications (Liu et al. 2015, Hyde et al. 2016). Combined datasets were aligned using MAFFT (Katoh \& Toh 2010, http://mafft.cbrc.jp/alignment/server/) and were manually optimized with BioEdit (Hall 2006) to allow maximum alignment. Maximum Parsimony analysis (MP) was performed with PAUP (Phylogenetic Analysis Using Parsimony) v. 4.0b10 (Swofford 2003). Gaps were treated as missing data, and the ambiguously aligned regions were excluded. Trees were inferred using the heuristic search option with Tree Bisection Reconnection branch swapping and 1000 random sequence additions. Maxtrees was set at 1000, branches of zero length were collapsed, and all multiple parsimonious trees were saved. Descriptive tree statistics for parsimony (tree length, consistency index, retention index, rescaled consistency index, and homoplasy index) were calculated for trees generated under different optimality criteria.

The best model of evolution for each gene region was determined with MRMODELTEST v. 2.2 (Nylander 2004), and maximum likelihood analyses were performed in RAXML GUI v. 0.9b2 (Silvestro \& Michalak 2010). The RAxML analyses were run with a rapid bootstrap analysis of a random starting tree and 1000 ML bootstrap replicates. The search strategy was set to rapid bootstrapping with one thousand non-parametric bootstrapping iterations using the general time reversible model (GTR) with a discrete gamma distribution. The best scoring trees were selected with final likelihood values. Posterior probabilities (PP) were determined by Markov Chain Monte Carlo sampling (BMCMC) in MrBayes v. 3.0b4 (Ronquist \& Huelsenbeck 2003). MrModeltest v. 2.3 (Nylander 2004) was used to perform statistical selection of the best-fit model of nucleotide substitution and was incorporated into the analysis. Six simultaneous Markov chains were run for $1,000,000$ generations, and the trees were sampled every $100^{\text {th }}$ generation. The 2000 trees representing the burn-in phase of the analyses were discarded, and the remaining 8000 trees were used for calculating PP in the majority rule consensus tree. The fungal strains isolated in this study are listed in Table 2 with details of the type cultures and sequence data. Novel sequence data were deposited in GenBank (Table 2), alignments in TreeBASE (www.treebase.org, submission no. S20936), and taxonomic novelties in the Faces of Fungi database (Jayasiri et al. 2015) and Index Fungorum (Index Fungorum 2016).

\section{Results}

\section{Phylogenetic analyses}

The collection of saprobic specimens from numerous woody hosts in Italy (Fig. 1) resulted in the isolation of 44 isolates of Diaporthe (Fig. 2). The ITS, TEF, BT and CAL sequences were determined to be approximately 530, 350, 510 and $410 \mathrm{bp}$, respectively.

The combined ITS, TEF, BT and CAL sequences of Diaporthe contained data for 144 isolates, including one outgroup taxon, and consisted of 44 isolates from this study and other sequences originating from GenBank (Table 3). Out of a total of 1998 characters, 882 were constant, and 295 were variable and parsimony uninformative. The remaining 821 parsimonyinformative characters resulted in 10 most parsimonious trees $(\mathrm{TL}=4190, \mathrm{CI}=0.464, \mathrm{RI}=0.883$, $\mathrm{RC}=0.410, \mathrm{HI}=0.536)$ and the best tree is shown in Fig. 2. The maximum parsimony $(\mathrm{MP})$ and Bayesian (BM) analyses produced trees with nearly identical topologies (Bayesian tree not shown). The isolates obtained in this study grouped into 15 distinct clades. The majority (12 isolates) grouped with the ex-epitype isolate of Diaporthe eres (AR5193); nine isolates clustered with the ex-epitype of D. foeniculina (CBS 111553); four isolates clustered with D. rhusicola (CBS 129528) and another four isolates clustered with D. rudis (AR3422). Moreover, four isolates grouped each with D. gulyae (BRIP 54025), D. novem (CBS 127270), D. ravennica (MFLUCC 15-0479) and D. sterilis (CBS 136969). Eleven isolates did not cluster with any known Diaporthe species and thus seven novel species, D. acericola, D. cichorii, D. dorycnii, D. lonicerae, D. pseudotsugae, D. schoeni and D. torilicola are introduced based on morphology and phylogenetic placement (Fig. 2). 

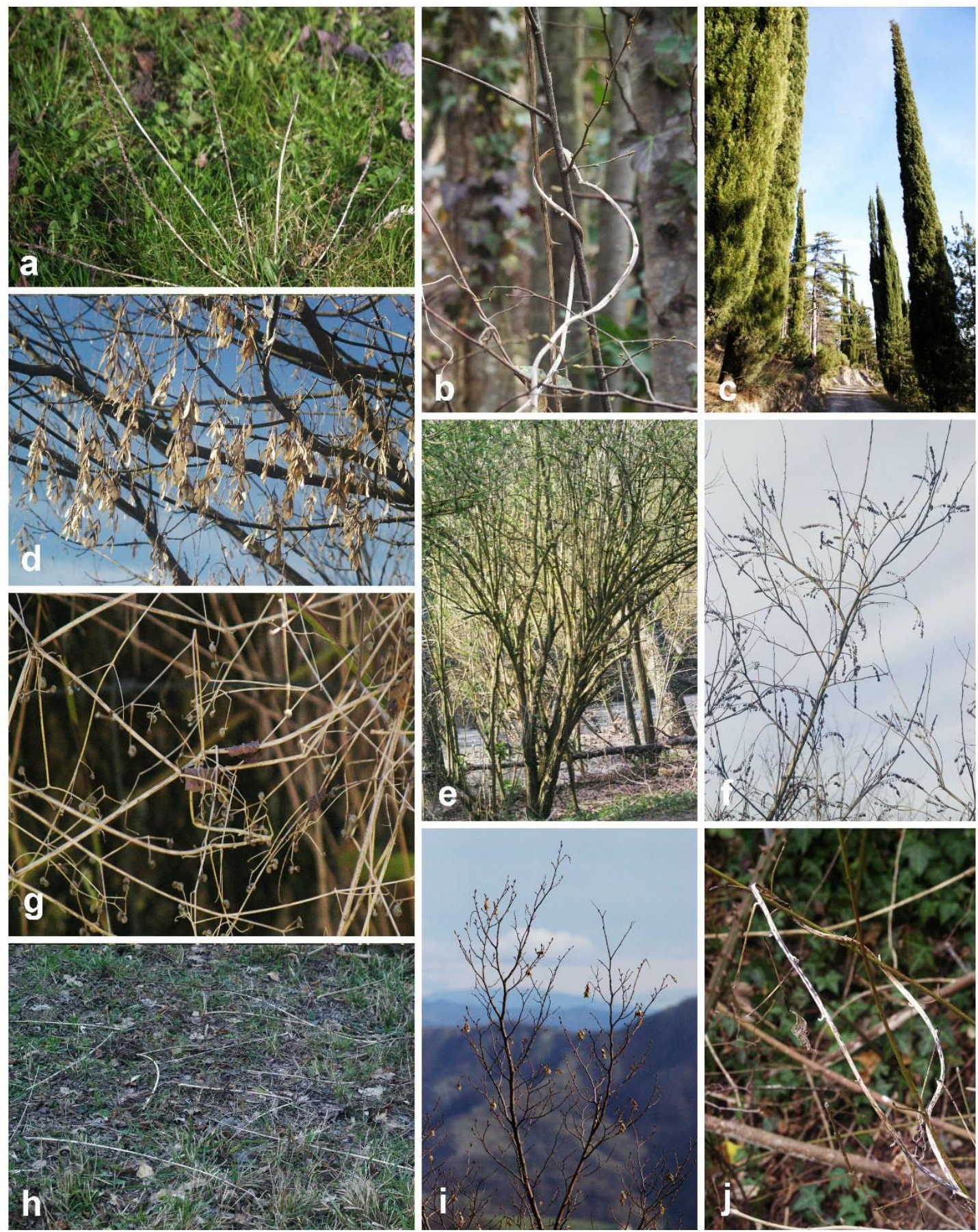

Figure 1 - Habitats of Diaporthe species in Italy. a Plantago sp., b Tamus communis on Rubus sp. and Ostrya carpinifolia. c Cupressus sempervirens. d Acer negundo. e Sambucus nigra. f Amorpha fruticosa. g Galium aparine. $\mathbf{h}$ land stem-leaf under Ailanthus altissima. i Ostrya carpinifolia. $\mathbf{j}$ Tamus communis on Cornus sanguinea. Photos by Erio Camporesi.

\section{Morphology and culture characteristics}

All 44 isolates identified based on the phylogenetic analyses using the combined data comprised 15 Diaporthe species (Diaporthe acericola, D. cichorii, D. dorycnii, D. eres, D. foeniculina, $D$. gulyae, $D$. lonicerae, $D$. novem, $D$. pseudotsugae, $D$. ravennica, $D$. rhusicola, $D$. rudis, D. schoeni, D. sterilis and D. torilicola) and were further characterized on the basis of colony morphology and conidial characteristics. Growth of all isolates was rapid on PDA, with mycelia covering the entire surface of the Petri dishes. Aerial mycelium was initially white and turned dirty white or greyish after 4-5 days of incubation at $25 \mathrm{C}$ in the dark. For all isolates, structures of the asexual morph appeared within 2-4 weeks of incubation. Sexual structures did not form on PDA throughout the growth period. All species showed morphological features typical of the genus. 


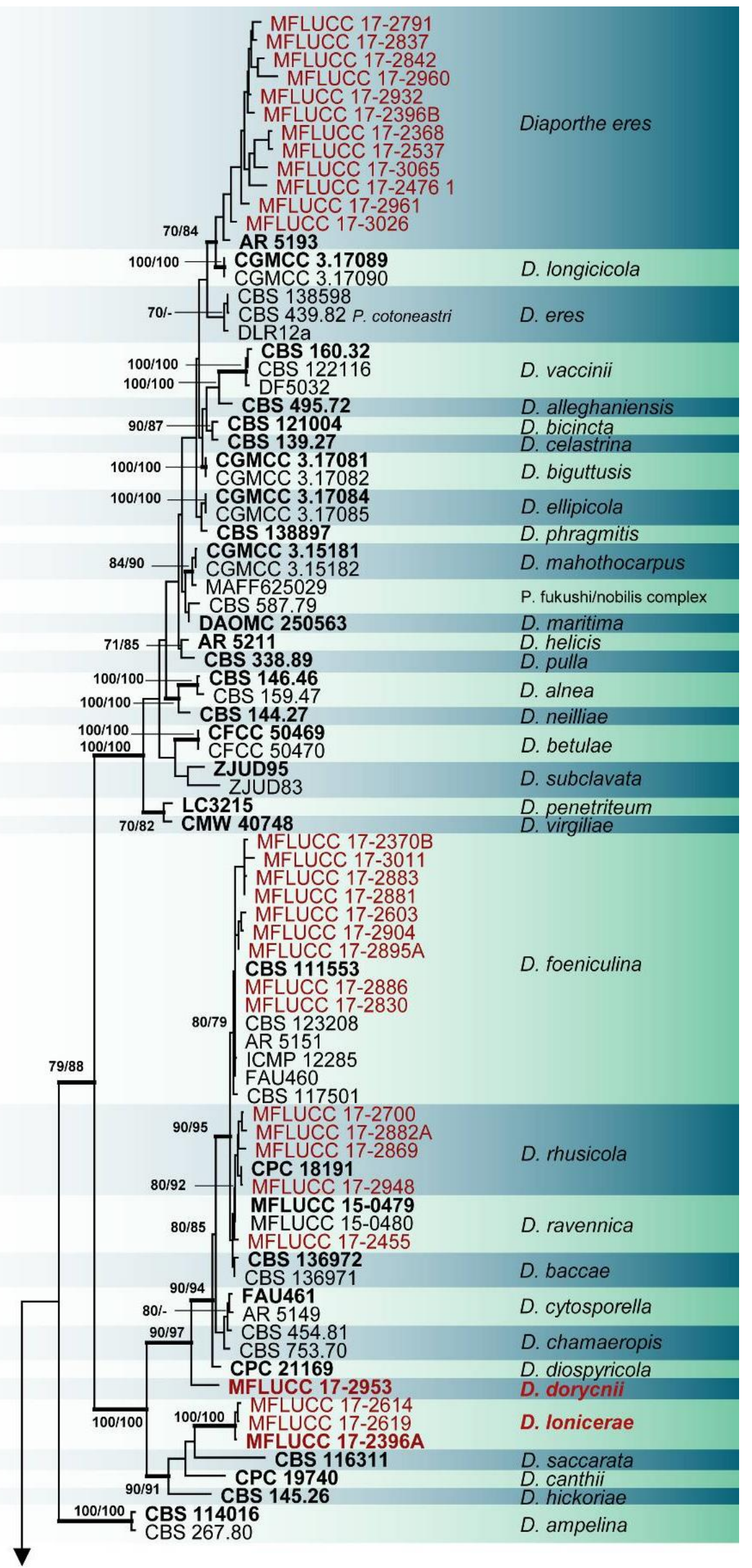




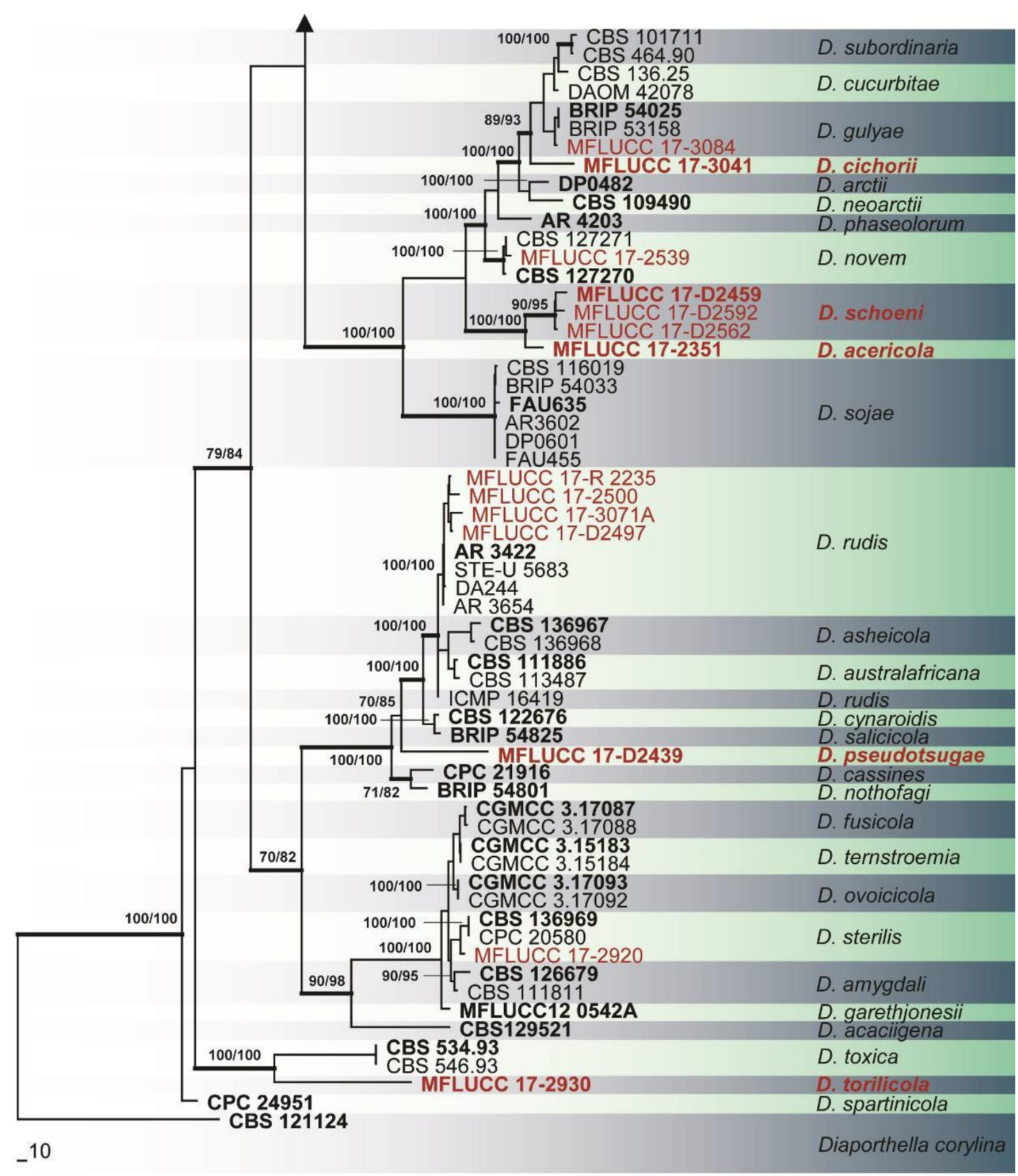

Figure 2 - Phylogram generated from maximum likelihood analysis of Diaporthe species isolated in this study and their phylogenetically closely related species based on combined ITS, TEF, BT and CAL sequence data. Parsimony bootstrap support values for $M L \geq 70 \%, M P \geq 70 \%$, are indicated above the nodes and the branches are in bold indicate Bayesian posterior probabilities $\geq 0.9$. The tree is rooted with Diaporthella corylina (CBS 121124). Isolate numbers of ex-types and reference strains are in bold. Taxa isolated in this study are in red and the ex-type isolate numbers of novel species are in bold.

The new species of Diaporthe described here are phylogenetically distinct from all previously described species for which sequence data are available.

\section{Taxonomy}

Seven undescribed species of Diaporthe were recognized by DNA sequence analysis, together with culture morphology, and with description of anamorphic structures. Two of the novel species, $D$. pseudotsugae and D. schoeni did not grow under the conditions used in this study and we could not obtain single conidial cultures. Therefore, DNA was extracted directly from the conidiomata/ascomata. 

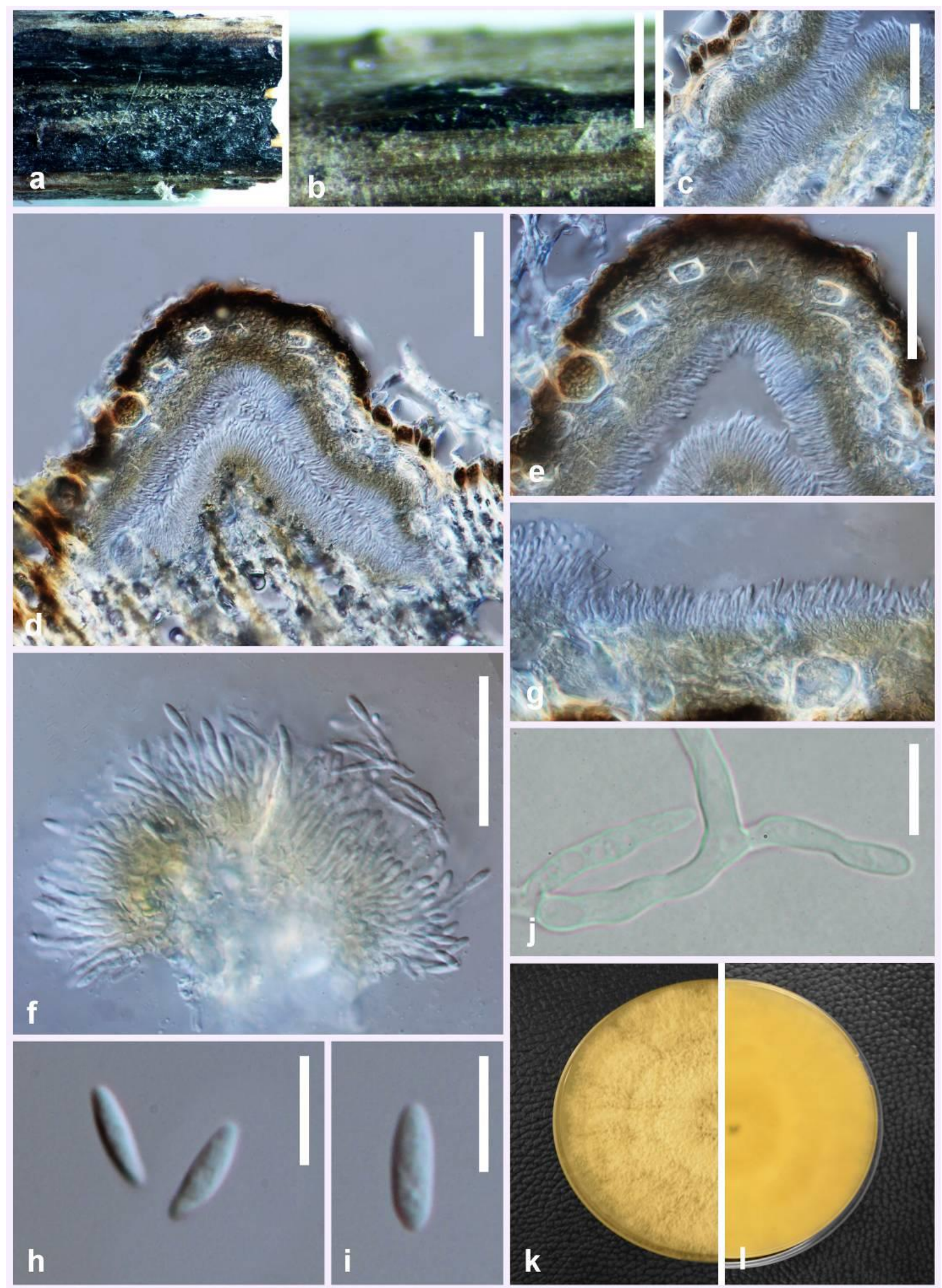

Figure 3 - Diaporthe acericola (MFLU 15-3254, holotype). a, b Conidiomata on host surface. d Cross section of conidioma. c,e Peridium. f, $\mathbf{g}$ Conidia attached to conidiogenous cells. h, i Alpha conidia. $\mathbf{j}$ Germinating spore. $\mathbf{k}$, $\mathbf{l}$ Culture on PDA after one week. Scale bars: $\mathrm{b}=0.5 \mathrm{~mm}, \mathrm{c}-\mathrm{f}=$ $100 \mu \mathrm{m}, \mathrm{g}-\mathrm{i}=10 \mu \mathrm{m}$. 
Index fungorum number: IF553186; Facesoffungi number: FoF 03270

Etymology - The specific epithet acericola is based on the host genus (Acer).

Holotype - MFLU 15-3254

Saprobic on aerial branch and samaras of Acer negundo L. Sexual morph: Not observed. Asexual morph: Conidiomata up to $460 \mu \mathrm{m}$ in diameter, $285 \mu \mathrm{m}$ high, superficial, solitary, scattered on host, oval, black. Peridium 65-77 $\mu \mathrm{m}$ thick, inner layer composed of light brown textura angularis, outer layer composed of dark brown textura angularis. Conidiophores $21-35 \times 1.5-2.5 \mu \mathrm{m}(\bar{x}=27 \times 2$ $\mu \mathrm{m})$, cylindrical, aseptate, densely aggregated, straight or sinuous, terminal, slightly tapered towards the apex. Conidiogenous cells $10-15 \times 2-3 \mu \mathrm{m}$, phialidic, cylindrical, terminal and lateral. Alpha conidia 9.7-13.5 $\times 3-4.5 \mu \mathrm{m}(\bar{x}=11 \times 4 \mu \mathrm{m})$, hyaline, fusiform or oval, both ends obtuse. Beta conidia not observed.

Culture characteristics - Colonies on PDA covering entire Petri dishes after seven days at $25{ }^{\circ} \mathrm{C}$, grey, with scant aerial mycelium; reverse fuscous black. Surface dirty white with profuse aerial mycelium, reverse umber.

Material examined - ITALY, Forlì-Cesena Province, San Colombano - Meldola, on dead aerial branches and samaras of Acer negundo (Sapindaceae), 22 January 2015, Erio Camporesi; (MFLU 15-3254, holotype); ex-type living culture MFLUCC 17-0956.

Notes - Diaporthe acericola forms a sister clade to D. schoeni which is also a new species introduced in this study (Fig. 2). However, the two species differed by 62 nucleotides in the concatenated alignment, of which 13 were distinct in the ITS region, 26 in the TEF region, 2 in the BT region and 21 in the CAL region. Morphologically, D. acericola differs from D. schoeni in having larger conidiomata and smaller conidia (Figs 3,8). Conidia of D. acericola are obtuse at both ends, while the conidia of $D$. schoeni are slightly acute and tapered at both ends.

Diaporthe cichorii Dissanayake, Camporesi \& K.D. Hyde, sp. nov.

Fig. 4

Index fungorum number: IF553187; Facesoffungi number: FoF 03271

Etymology - The specific epithet cichorii is based on the host genus (Cichorium).

Holotype - MFLU 16-2168

Saprobic on dead aerial stem of Cichorium intybus L. Sexual morph: Not observed. Asexual morph: Conidiomata up to $540 \mu \mathrm{m}$ in diameter, $390 \mu \mathrm{m}$ high, superficial, solitary or aggregated, globose to oval, dark brown to black, clustered in groups of 2-5 conidiomata. Peridium 47-58 $\mu \mathrm{m}$ thick, inner layer composed of light brown textura angularis, outer layer composed of dark brown textura angularis. Conidiophores $24-37 \times 1.5-3 \mu \mathrm{m}(\bar{x}=29 \times 3 \mu \mathrm{m})$, cylindrical, aseptate, densely aggregated, straight or sinuous, terminal, slightly tapered towards the apex. Conidiogenous cells 7$10 \times 2-3 \mu \mathrm{m}$, hyaline, subcylindrical, filiform, straight to curved, tapering towards the apex. Alpha conidia $10-14 \times 3-4 \mu \mathrm{m}(\bar{x}=12 \times 3 \mu \mathrm{m})$ hyaline, fusiform or oval, both ends obtuse. Beta conidia not observed.

Culture characteristics - Colonies on PDA flat, with an entire edge, mycelium growing in concentric rings, cottony texture, white to smoke-grey; colonies reaching up to $64 \mathrm{~mm}$ diameter after one week at $25^{\circ} \mathrm{C}$; reverse buff and isabelline.

Material examined - ITALY, Forlì-Cesena Province, Santa Sofia, on dead aerial stem of Cichorium intybus (Asteraceae), 17 July 2016, Erio Camporesi; (MFLU 16-2168, holotype); extype living culture MFLUCC 17-1023.

Notes - Diaporthe cichorii occurs in a clade separate from D. gulyae, D. cucurbitae and D. subordinaria and differs from $D$. gulyae by 19 nucleotides in the concatenated alignment, in which 7 were distinct in the ITS region and 12 in the TEF region. Though the sequences of BT region and CAL region are available for $D$. cichorii, the sequences of those regions are unavailable for $D$. gulyae. Morphologically, the conidiomata of $D$. gulyae are up to $3 \mathrm{~mm}$ in diam, whereas in $D$. cichorii they are up to $540 \mu \mathrm{m}$ in diameter Alpha conidia of D. gulyae are smaller $(6.5-9 \mu \mathrm{m})$ compared to those of $D$. cichorii $(10-14 \mu \mathrm{m})$. 

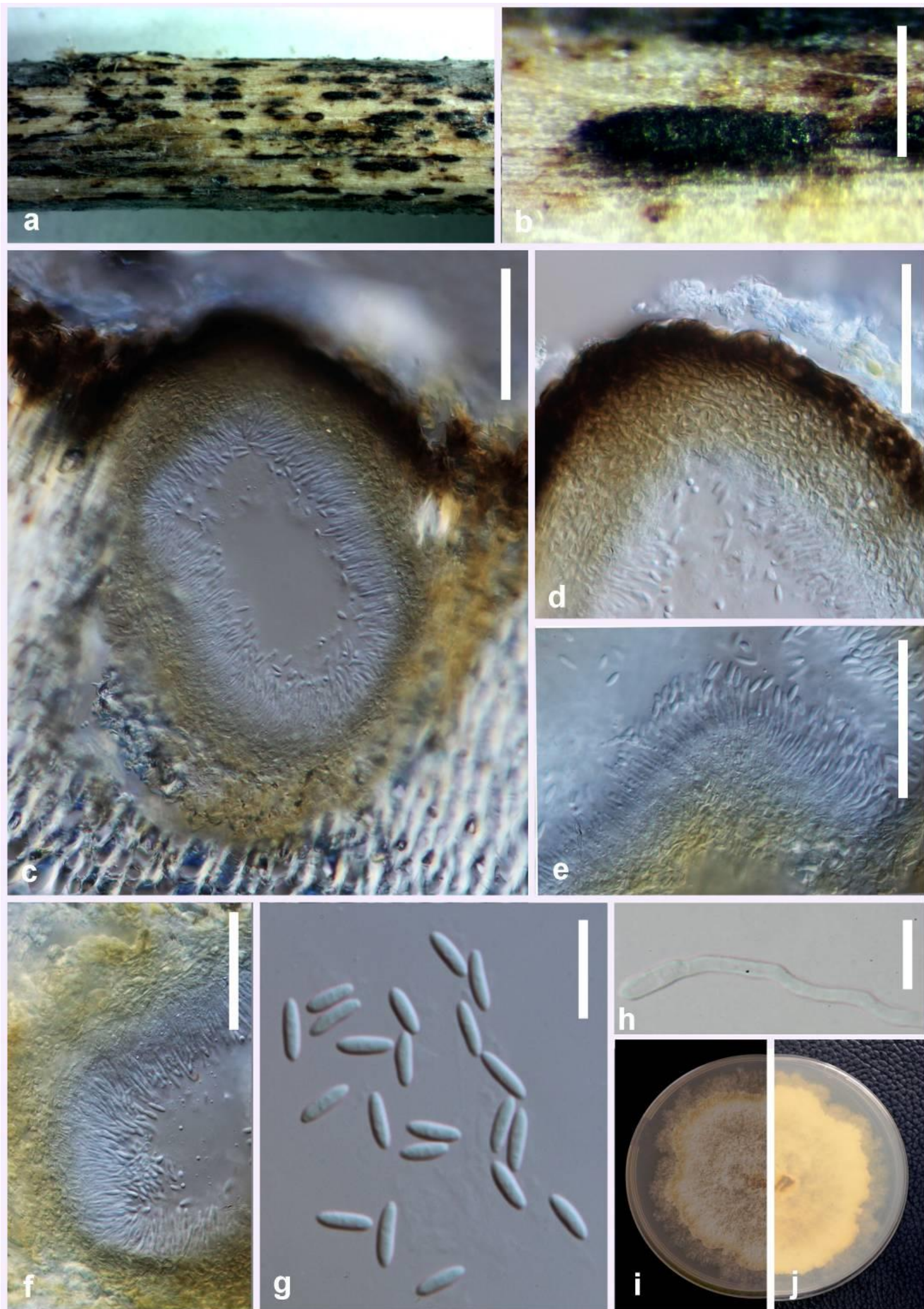

Figure 4 - Diaporthe cichorii (MFLU 16-2168, holotype). a, b Conidiomata on host surface. c Cross section of conidioma. d Peridium. e, $\mathbf{f}$ Conidia attached to conidiogenous cells. $\mathbf{g}$ Alpha conidia. $\mathbf{h}$ Germinating spore. $\mathbf{i}, \mathbf{j}$ Culture on PDA after one week. Scale bars: $b=1 \mathrm{~mm}, \mathrm{c}-\mathrm{f}=100$ $\mu \mathrm{m}, \mathrm{g}=20 \mu \mathrm{m}, \mathrm{h}=10 \mu \mathrm{m}$. 

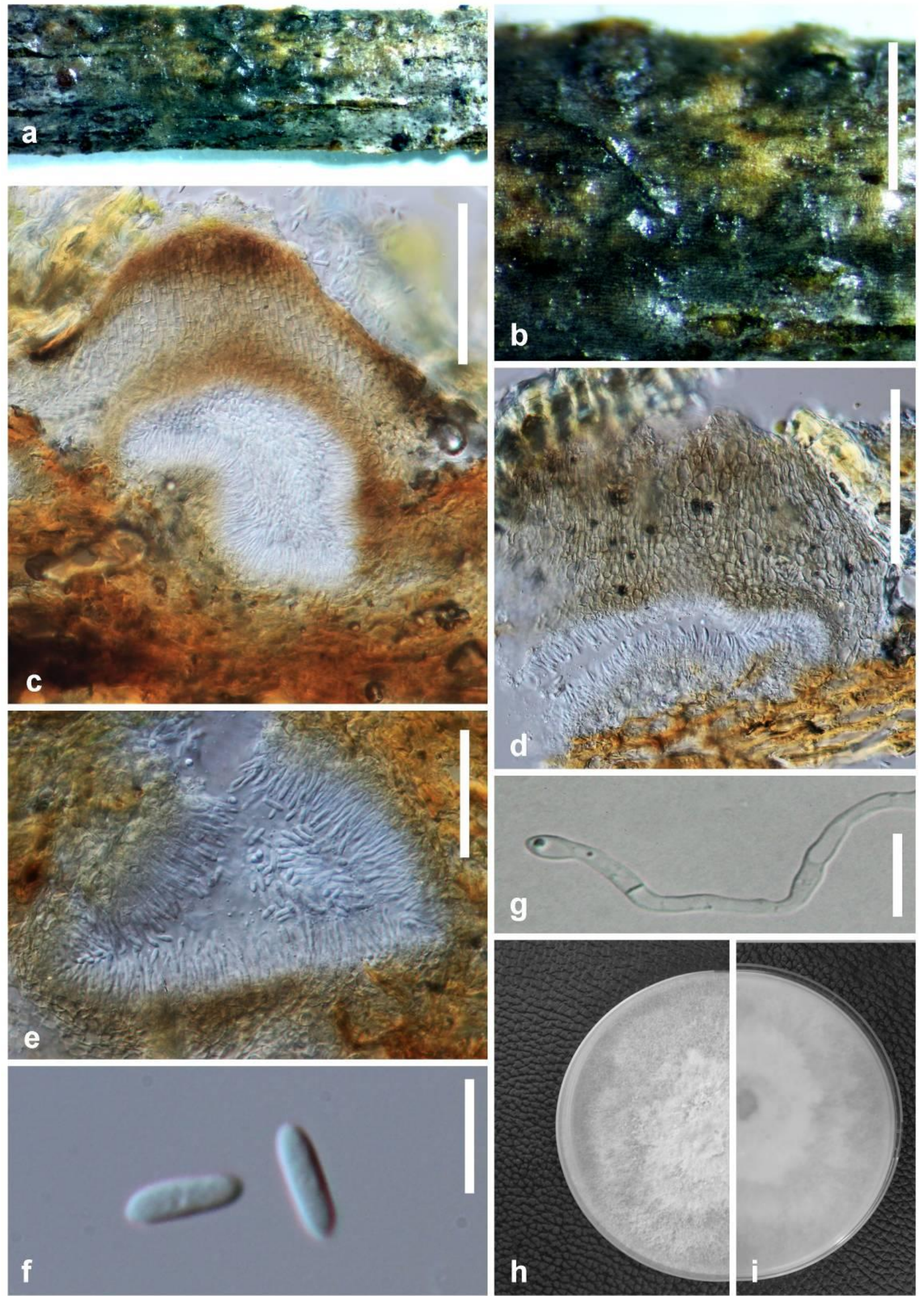

Figure 5 - Diaporthe dorycnii (MFLU 16-1322, holotype). a, b Conidiomata on host surface. c Cross section of conidioma. d Peridium. e, Conidia attached to conidiogenous cells. $\mathbf{f}$ Alpha conidia. g Germinating conidium. h, i Culture on PDA after one week. Scale bars: $b=1 \mathrm{~mm}, \mathrm{c}-\mathrm{e}=$ $100 \mu \mathrm{m}, \mathrm{f}=10 \mu \mathrm{m}, \mathrm{g}=20 \mu \mathrm{m}$. 
Index fungorum number: IF553188; Facesoffungi number: FoF 03272

Etymology - The specific epithet dorycnii is based on the host genus (Dorycnium).

Holotype - MFLU 16-1322

Saprobic on dead aerial stem of Dorycnium hirsutum L. Sexual morph: Not observed. Asexual morph: Conidiomata up to $420 \mu \mathrm{m}$ in diameter, $380 \mu \mathrm{m}$ high, superficial or immersed, solitary or gregarious, scattered on host surface, globose, dark brown to black, clustered in groups of 2-5 conidiomata. Peridium 35-50 $\mu \mathrm{m}$ thick, inner layer composed of light brown textura angularis, outer layer composed of dark brown textura angularis. Conidiophores 21-35 × 1.5-2.5 $\mu \mathrm{m}(\bar{x}=27 \times 2 \mu \mathrm{m})$, cylindrical, aseptate, densely aggregated, straight or sinuous, terminal, slightly tapered towards the apex. Conidiogenous cells 13-19 $\times 2-3 \mu \mathrm{m}$ hyaline, subcylindrical and filiform, straight, tapering towards the apex. Alpha conidia 9-13.5 $\times 3-4 \mu \mathrm{m}(\bar{x}=11 \times 4 \mu \mathrm{m})$ hyaline, biguttulate, fusiform or oval, both ends obtuse. Beta conidia not observed.

Culture characteristics - Colonies on PDA covering entire Petri dishes after 10 days, flat, with an entire edge, aerial mycelium forming concentric rings with cottony texture, white, olivaceous on surface.

Material examined - ITALY, Forlì-Cesena Province, Fiumicello di Premilcuore, on dead aerial stem of Dorycnium hirsutum (Fabaceae), 2 May 2016, Erio Camporesi; (MFLU 16-1322, holotype); ex-type living culture MFLUCC 17-1015.

Notes - Diaporthe dorycnii occurs in a clade separate from $D$. diospyricola, $D$. chamaeropsis and D. cytosporella with high bootstrap support (Fig. 2). Diaporthe diospyricola differs from $D$. dorycnii, in the presence of beta conidia. Phylogenetically, D. diospyricola is the closest species to $D$. dorycnii (Fig. 2), differing by 24 nucleotides in the ITS region. Though the sequences of EF region, BT region and CAL region are available for $D$. dorycnii, the sequences of those regions are unavailable for $D$. diospyricola and thus the nucleotide comparison is incomplete.

Diaporthe lonicerae Dissanayake, Camporesi \& K.D. Hyde, sp. nov.

Fig. 6

Index fungorum number: IF553189; Facesoffungi number: FoF 03273

Etymology - The specific epithet lonicerae is based on the host genus (Lonicera).

Holotype - MFLU 15-3511

Saprobic on dead aerial branch of Lonicera sp. Sexual morph: Not observed. Asexual morph: Conidiomata up to $680 \mu \mathrm{m}$ in diameter, superficial, solitary, scattered on PDA, globose, dark brown to black, clustered in groups of 2-5 pycnidia. Peridium 15-60 $\mu \mathrm{m}$ thick, inner layer composed of light brown textura angularis, outer layer composed of dark brown textura angularis. Conidiophores $21-35 \times 1.5-2.5 \mu \mathrm{m}(\bar{x}=27 \times 2 \mu \mathrm{m})$, cylindrical, aseptate, densely aggregated, straight or sinuous, terminal, slightly tapered towards the apex.

Conidiogenous cells $8-11 \times 2-3 \mu \mathrm{m}$ hyaline, subcylindrical, straight to curved, tapering towards the apex. Alpha conidia 12.5-16 $\times 3.5-4 \mu \mathrm{m}(\bar{x}=14.5 \times 4 \mu \mathrm{m})$ hyaline, biguttulate, fusiform or oval, both ends obtuse. Beta conidia $32-39 \times 1-1.5 \mu \mathrm{m}(\bar{x}=36 \times 1.5 \mu \mathrm{m})$ hyaline, aseptate, filiform, hamate, tapering towards both ends.

Culture characteristics - Colonies on PDA covering entire Petri dishes after 10 days, flat, with an entire edge, aerial mycelium forming irregular concentric rings with cottony texture, olivaceous-buff, isabelline to honey on surface.

Material examined - ITALY, Forlì-Cesena Province, Predappio Alta, on dead aerial branch of Lonicera sp. (Caprifoliaceae), 28 Febrary 2015, Erio Camporesi; (MFLU 15-3511, holotype); ex-type living culture MFLUCC 17-0963.

Notes - Diaporthe lonicerae clusters closer to D. saccarata, D. canthi and D. hickoriae. Phylogenetically, D. saccarata is the closest species to D. lonicerae (Fig. 2), differing by 107 nucleotides in the concatenated alignment, in which 19 were distinct in the ITS region, 34 in the TEF region, 16 in the $\mathrm{BT}$ region and 38 in the CAL region. Both species possess beta conidia and morphologically, D. saccarata differs from D. lonicerae, in having 1-septate alpha conidia (Mostert et al. 2001). 

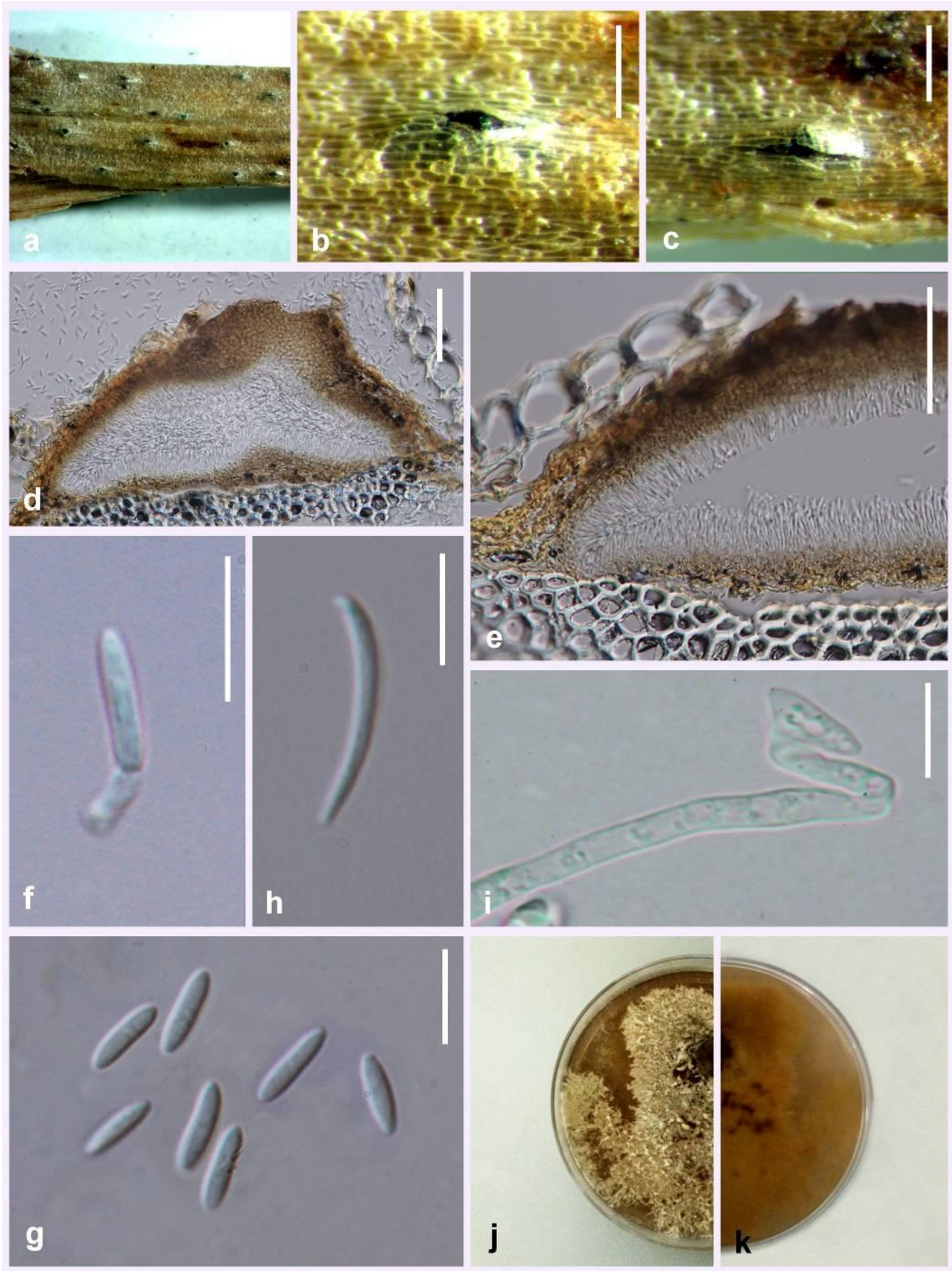

Figure 6 - Diaporthe lonicerae (MFLU 15-3511, holotype). a-c Conidiomata on host surface. d Cross section of conidioma. e Peridium. f Alpha conidium attached to conidiogenous cells. $\mathbf{g}$ Alpha conidia. $\mathbf{h}$ Beta conidium. i Germinating conidium. $\mathbf{j}$, $\mathbf{k}$ Culture on PDA after two weeks. Scale bars: $\mathrm{b}, \mathrm{c}=1 \mathrm{~mm}, \mathrm{~d}, \mathrm{e}=100 \mu \mathrm{m}, \mathrm{f}, \mathrm{g}=15 \mu \mathrm{m}$. 



Figure 7 - Diaporthe pseudotsugae (MFLU 15-3228, holotype). a, b Ascomata on host surface. c Cross section of ascoma. d Peridium. e Immature ascus. f Immature ascus immersed in Indian ink. $\mathbf{g}$ Mature ascus. $\mathbf{h}$ Mature ascus mounted in methylene blue. $\mathbf{i}$ Cluster of immature asci. $\mathbf{j}$ ascospore. Scale bars: $b=1 \mathrm{~mm}, \mathrm{c}, \mathrm{d}=100 \mu \mathrm{m}, \mathrm{e}-\mathrm{i}=30 \mu \mathrm{m}, \mathrm{j}=20 \mu \mathrm{m}$.

Diaporthe pseudotsugae Dissanayake, Camporesi \& K.D. Hyde, sp. nov. Fig. 7 Index fungorum number: IF553190; Facesoffungi number: FoF 03274 Etymology - The specific epithet pseudotsugae is based on the host genus (Pseudotsuga). Holotype - MFLU 15-1274 
Saprobic on dead land cones of Pseudotsuga menziesii (Mirb.). Sexual morph: Ascomata up to $465 \mu \mathrm{m}$ in diameter, $255 \mu \mathrm{m}$ high, black, globose to oval, clustered in groups, deeply immersed in host tissue protruding through substrata. Peridium 28-42 $\mu \mathrm{m}$ thick, inner layer composed of light brown textura angularis, outer layer composed of dark brown textura angularis. Asci $60-85 \times 21-$ $37 \mu \mathrm{m}(\bar{x}=75 \times 29 \mu \mathrm{m})$, unitunicate, 8-spored, sessile, elongate to clavate. Ascospores 19-21 $\times 6-$ $8 \mu \mathrm{m}(\bar{x}=20 \times 7 \mu \mathrm{m})$, hyaline, two-celled, often 4-guttulate, with larger guttules at centre and smaller ones at the ends, elongated to elliptical. Asexual morph: Not observed.

Material examined - ITALY, Forlì-Cesena Province, Premilcuore, on dead land cones of Pseudotsuga menziesii (Pinaceae), 10 April 2015, Erio Camporesi; (MFLU 15-1274, holotype).

Notes - We could not obtain a culture from single ascospore. Therefore, DNA was extracted directly from the ascomata. Diaporthe pseudotsugae occurs in a clade separate from $D$. salicicola, D. cynaroidis, D. cassines and D. nothofagi. Although D. pseudotsugae is a sexual morph, none of the above mentioned species possess any sexual morph. Phylogenetically, $D$. cassines is the closest species to D. pseudotsugae (Fig. 2), differing by 64 nucleotides in the concatenated alignment, in which 34 were distinct in the ITS region, 30 in the TEF region. Though the sequences of BT region and CAL region are available for D. pseudotsugae, the sequences of those regions are unavailable for $D$. cassines.

Diaporthe schoeni Dissanayake, Camporesi \& K.D. Hyde, sp. nov.

Fig. 8

Index fungorum number: IF553191; Facesoffungi number: FoF 03275

Etymology - The specific epithet schoeni is based on the host genus (Schoenus).

Holotype - MFLU 15-1279

Saprobic on dead aerial stem of Schoenus nigricans L. Sexual morph: Not observed. Asexual morph: Conidiomata up to $210 \mu \mathrm{m}$ in diameter, $110 \mu \mathrm{m}$ high, immersed, solitary or gregarious, scattered on host surface, globose to oval, dark brown to black. Peridium 9-32 $\mu \mathrm{m}$ thick, inner layer composed of light brown textura angularis, outer layer composed of dark brown textura angularis. Conidiophores absent, Conidiogenous cells $21-35 \times 1.5-2.5 \mu \mathrm{m}(\bar{x}=27 \times 2$ $\mu \mathrm{m})$, cylindrical, aseptate, densely aggregated, straight or sinuous, terminal, slightly tapered towards the apex. Alpha conidia 11-14.5 $\times 2-3 \mu \mathrm{m}(\bar{x}=13.5 \times 3 \mu \mathrm{m})$, hyaline, fusiform or oval, both ends slightly acute and tapered. Beta conidia $21-33 \times 1-1.5 \mu \mathrm{m}(\bar{x}=27 \times 1.5 \mu \mathrm{m})$, rarely found among alpha conidia, hyaline, aseptate, filiform, hamate, tapering towards both ends.

Material examined - ITALY, Ravenna Province, Lido di Dante, on dead aerial stem of Schoenus nigricans (Cyperaceae), 1 May 2015, Erio Camporesi; (MFLU 15-1279, holotype).

Notes - We could not obtain a culture from single conidia. Therefore, fungal DNA was extracted directly from the conidiomata. Three isolates of $D$. schoeni were isolated from three different hosts, Carduus sp. (Asteraceae), Plantago sp. (Plantaginaceae) and Schoenus nigricans (Cyperaceae). However, any of those isolates were failed to germinate. Diaporthe schoeni occurs in a clade closer to $D$. acericola (Fig. 2). Both species can be differentiated by smaller conidiomata and larger conidia of $D$. schoeni. Conidia of $D$. acericola are obtuse at both ends, while the conidia of D. schoeni are slightly acute and tapered at both ends (Figs 3,8). Phylogenetically, D. schoeni differs from $D$. acericola by 62 nucleotides in the concatenated alignment, of which 13 were distinct in the ITS region, 26 in the TEF region, 2 in the BT region and 21 in the CAL region.

Diaporthe torilicola Dissanayake, Camporesi \& K.D. Hyde, sp. nov.

Fig. 9

Index fungorum number: IF553192; Facesoffungi number: FoF 03276

Etymology - The specific epithet torilicola is based on the host genus (Torilis).

Holotype - MFLU 16-1166

Pathogenic on Torilis arvensis (Huds.). Sexual morph: Not observed. Asexual morph: Conidiomata up to $300 \mu \mathrm{m}$ in diameter, superficial, solitary, scattered on PDA, globose, dark brown to black, clustered in groups of 2-5 pycnidia. Peridium 16-20 $\mu \mathrm{m}$ thick, inner layer composed of light brown textura angularis, outer layer composed of dark brown textura angularis. Conidiophores $21-35 \times 1.5-2.5 \mu \mathrm{m}(\bar{x}=27 \times 2 \mu \mathrm{m})$, cylindrical, aseptate, densely aggregated, 

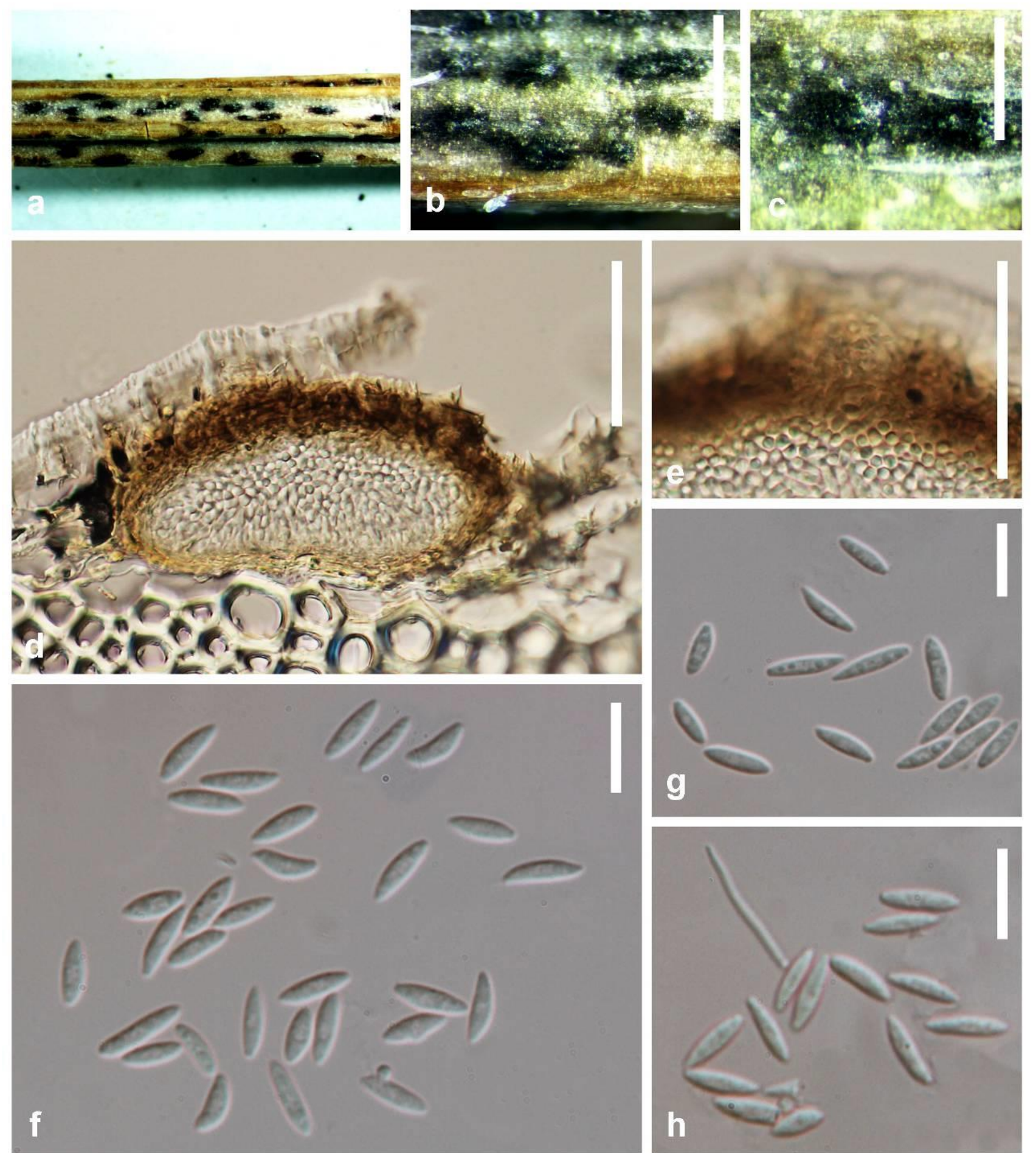

Figure 8 - Diaporthe schoeni (MFLU 15-1279, holotype). a-c Conidiomata on host surface. d Cross section of conidiomata. e Peridium. f, $\mathbf{g}$ Alpha conidia. $\mathbf{h}$ Alpha conidia with a beta conidium. Scale bars: $\mathrm{b}, \mathrm{c}=1 \mathrm{~mm}, \mathrm{~d}, \mathrm{e}=100 \mu \mathrm{m}, \mathrm{f}-\mathrm{h}=15 \mu \mathrm{m}$.

straight or sinuous, terminal, slightly tapered towards the apex. Alpha conidia $6-8.5 \times 2-3 \mu \mathrm{m}(\bar{x}=$ $8 \times 3 \mu \mathrm{m})$ hyaline, biguttulate, fusiform or oval, both ends obtuse. Beta conidia $18-37 \times 1-1.5 \mu \mathrm{m}$ $(\bar{x}=27 \times 1.5 \mu \mathrm{m})$ hyaline, aseptate, filiform, hamate, guttulate, tapering towards both ends.

Culture characteristics - Colonies on PDA covering entire Petri dishes after 10 days, grey, with scant aerial mycelium; reverse fuscous black. Colonies on PDA flat, with entire edge, cottony, olivaceous buff, with aerial mycelium in concentric rings, with olivaceous patches; colonies reaching entire petri dish after $2 \mathrm{wk}$ at $25^{\circ} \mathrm{C}$; reverse olivaceous buff and greenish olivaceous. 

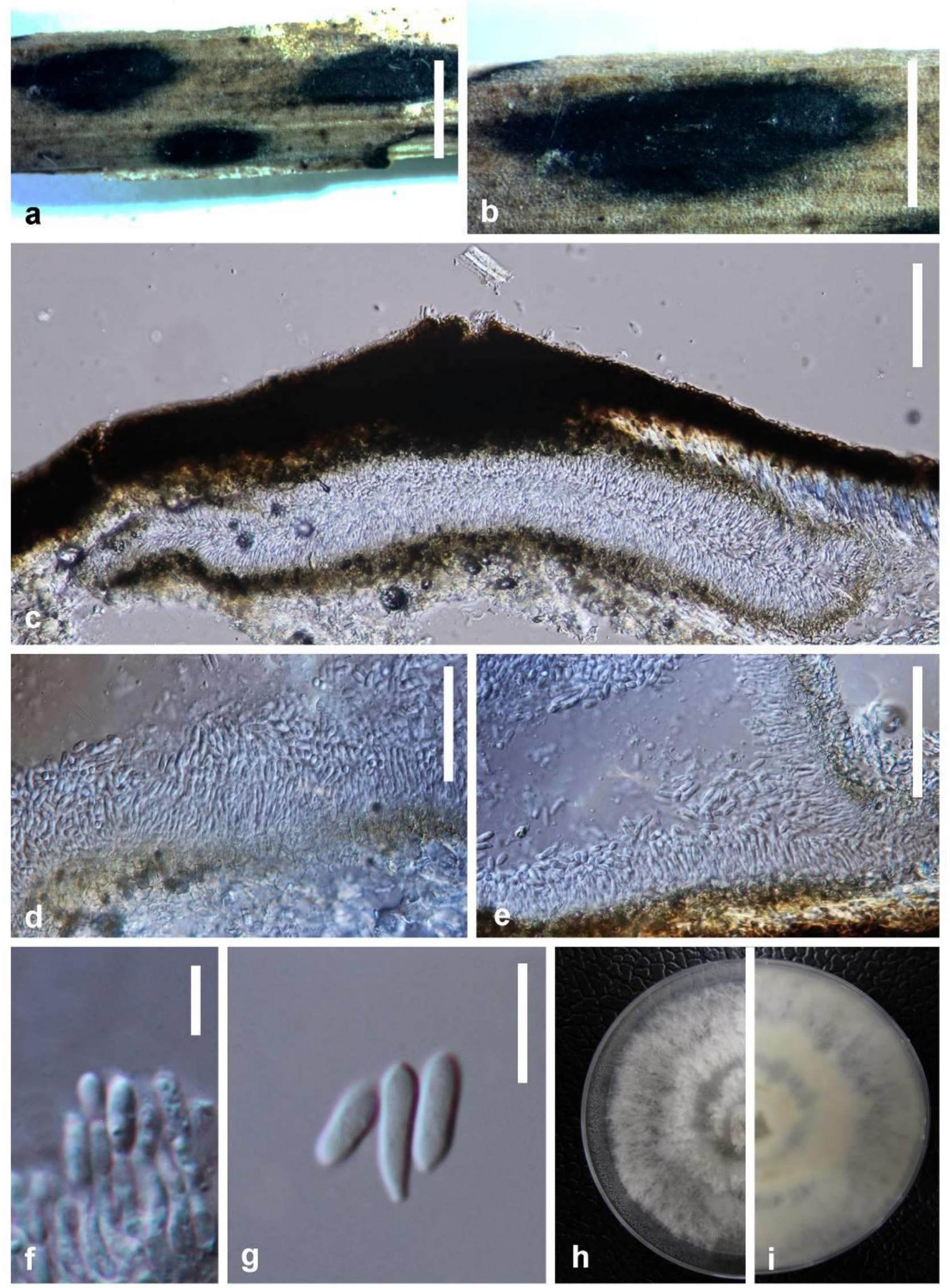

Figure 9 - Diaporthe torilicola (MFLU 16-1166, holotype). a, b Conidiomata on host surface. c Cross section of conidiomata. $\mathbf{d}-\mathbf{f}$ Conidia attached to conidiogenous cells. $\mathbf{g}$ Alpha conidia. $\mathbf{h}, \mathbf{i}$ Culture on PDA after one week. Scale bars: $a, b=0.5 \mathrm{~mm}, \mathrm{c}-\mathrm{e}=100 \mu \mathrm{m}, \mathrm{f}, \mathrm{g}=10 \mu \mathrm{m}$. 
Material examined - ITALY, Forlì-Cesena Province, Monte Pallareto - Meldola dead aerial stem of Torilis arvensis (Apiaceae), 12 April 2016, Erio Camporesi; (MFLU 16-1166, holotype); ex-type living culture MFLUCC 17-1051.

Notes - In the phylogenetic analysis, D. torilicola forms a sister clade to $D$. toxica. Williamson et al. (1994) designated the name D. toxica for the sexual state of the toxicogenic variety, P. leptostromiformis var. leptostromiformis. Phylogenetically, D. toxica differs from $D$. torilicola by 92 nucleotides in the concatenated alignment, in which 26 were distinct in the ITS region, 27 in the TEF region, 17 in the $\mathrm{BT}$ region and 22 in the CAL region.

\section{Discussion}

Studies on Diaporthe, dealing with the phylogenetic traits and morphology of isolates associated with various hosts, have increased in recent years, enabling the worldwide identification of taxa at the species level (Gomes et al. 2013, Udayanga et al. 2014a, b). In this study, seven new species have been described in Diaporthe, on the basis of morphological and molecular characteristics. Two of the novel species, D. pseudotsugae and D. schoeni did not grow under the conditions of this study and single spore isolates could not be obtained. In addition to the new species, eight known species of Diaporthe (D. eres, D. foeniculina, D. gulyae, D. novem, D. ravennica, D. rhusicola, D. rudis and D. sterilis) were identified. Apart from D. eres, D. foeniculina and $D$. ravennica; none of the other species were identified in previous studies on Italian hosts, which probably implies an association with geographic origin and/or host species. A phylogenetic tree derived from an alignment of ITS sequences is beneficial as a guide for identification of isolates of Diaporthe species (Udayanga et al. 2012, Tan et al. 2013). ITS sequences offer convincing proof for species demarcation where a limited number of taxa are analyzed, such as species associated with the same host (Santos \& Phillips 2009, Santos et al. 2011, Thompson et al. 2011). However, confusion arises when a large number of species from an extensive range of host species are examined. Santos et al. (2010) proposed that TEF is a superior phylogenetic marker in Diaporthe than ITS, and has been commonly used as a secondary locus for phylogenetic studies (Santos et al. 2011, Udayanga et al. 2012, Dissanayake et al. 2015). Gomes et al. (2013) studied five loci from 95 species. They stated that TEF poorly distinguished species, and recommended that histone and BT were suitable possibilities as subordinate phylogenetic markers to accompany the authorized fungi barcode, ITS. In this study, a combined four gene analyses of ITS, TEF, BT and CAL was used to study eight known Diaporthe species and to assist in the introduction of seven new Diaporthe species.

Diaporthe eres was the most frequent species in the present study, comprising $27 \%$ of the isolates, and was associated with Galega officinalis (Fabaceae), Juglans regia (Juglandaceae), Lonicera sp. (Caprifoliaceae), Ostrya carpinifolia (Betulaceae), Picea excels (Pinaceae), Pinus pinaster (Pinaceae), Populus nigra (Salicaceae), Rhamnus alpinus (Rhamnaceae), Salix caprea (Salicaceae), Sambucus nigra (Adoxaceae), Sanguisorba minor (Rosaceae) and Sonchus oleraceus (Asteraceae) in the provinces of Arezzo and Forlì-Cesena (Table 2). In all of the studies conducted in Italy, involving gene sequencing, this species was detected as the most common, but not the most virulent (Gomes et al. 2013, Cinelli et al. 2016, Udayanga et al. 2015). Phylogenetic studies indicated that, as well as the aforementioned phenomenon, there is low posterior probability support between the internal branches of the $D$. eres clade, indicating a large intraspecific diversity in this species (Gomes et al. 2013, Dissanayake et al. 2017a, b). After several phylogenetic studies of D. eres, from 2005 to the present day, including sampled plants and areas previously unexplored, it was shown how this morphological species is complex, harbouring several cryptic species with various hosts in different geographical locations (Crous 2005, Gao et al. 2016, Gomes et al. 2013, Dissanayake et al. 2015, 2017a, Udayanga et al. 2014b).

Diaporthe foeniculina was the second most common species, with $20 \%$ of the isolates in this study, and was associated with Achillea millefolium (Asteraceae), Ailanthus altissima (Simaroubaceae), Arctium minus (Asteraceae), Cupressus sepervirens (Cupressaceae), Hemerocallis fulva (Hemerocallidoiceae), Lunaria rediviva (Brassicaceae), Melilotus officinalis 
(Fabaceae), Vicia sp. (Fabaceae) and Wisteria sinensis (Fabaceae) in the provinces of Arezzo and Forlì-Cesena (Table 2). Recently, D. foeniculina was epitypified by Udayanga et al. (2014a) and the utility of individual genes for accurate circumscription of this species was assessed. Diaporthe foeniculina, including the synonym $D$. neotheicola, is recognized as a species with an extensive host range (Udayanga et al. 2014a). Regarding D. neotheicola, this species has been reported to cause diseases of temperate and tropical fruits in Australia, Europe and South Africa (Golzar et al. 2012, Thomidis et al. 2013).

Diaporthe rudis was isolated from Anthoxanthum odoratum (Poaceae), Carlina vulgaris (Asteraceae), Cornus sp. (Cornaceae) and Dioscorea communis (Dioscoreaceae). Since its description, this species has been identified around the world as being associated with numerous hosts (Udayanga et al. 2014a, Chen et al. 2014a, b, Huang et al. 2015, Lombard et al. 2014), which highlights its high degree of dissemination, distribution and wide host range, similar to $D$. eres. Udayanga et al. (2014a) determined $D$. viticola to be a synonym of $D$. rudis, which was previously recognized as a distinct taxon.

Diaporthe rhusicola occurred at the same frequency as D. rudis, with $9 \%$ of isolates taken from dead aerial stem or branch in Amorpha fruticosa (Fabaceae), Angelica sylvestris (Apiaceae), Platanus hybrida (Platanaceae) and Rubus sp. (Rosaceae). Diaporthe rhusicola was described and first reported in South Africa as causing leaf spots of Rhus pendulina (Crous et al. 2011) and was subsequently proved to be pathogenic in English walnut (Chen et al. 2014b) and pistachio in California (Chen et al. 2014a). The other known Diaporthe species (D. gulyae, D. novem, D. ravennica and D. sterilis) were isolated from Italian hosts Heracleum sphondylium (Apiaceae), Galium sp. (Rubiaceae), Salvia sp. (Lamiaceae) and Cytisus sp. (Fabaceae) respectively.

Except for D. lonicerae and D. schoeni, all other novel species identified in this study were associated with only one host (Table 2). Diaporthe acericola, D. cichorii, D. dorycnii, D. pseudotsugae, and D. torilicola were isolated from Acer negundo (Sapindaceae), Cichorium intybus (Asteraceae), Dorycnium hirsutum (Fabaceae), Pseudotsuga menziesii (Pinaceae) and Torilis arvensis (Apiaceae) respectively. Diaporthe lonicerae was isolated from Lonicera sp. (Caprifoliaceae), Laurus nobilis (Lauraceae) and Torilis arvensis (Apiaceae) in Forlì-Cesena province, while D. schoeni was isolated from Schoenus nigricans (Cyperaceae), Carduus sp. (Asteraceae) and Plantago sp. (Plantaginaceae) in Arezzo, Forlì-Cesena and Ravenna provinces.

The discovery of these species of Diaporthe on diverse hosts and in different geographical localities in Italy as well as worldwide shows the polyphagous and cosmopolitan behavior of species in this genus. Certainly, it is obvious that performing complementary studies based on sequencing at least four gene regions of Diaporthe species is essential in order to support reliable species identification. Such studies are necessary to investigate this group of fungi in different unexploited biomes, to reveal the degree of diversity and to support more suitable control measures to prevent their dissemination.

\section{Acknowledgements}

This work was financed by JNKYT201605, Innovation funds of IPEP, BAAFS and CARS30.

\section{References}

Annesi T, Luongo L, Vitale S, Galli M, Belisario A. 2016 - Characterization and pathogenicity of Phomopsis theicola anamorph of Diaporthe foeniculina causing stem and shoot cankers on sweet chestnut in Italy. Journal of Phytopathology 164, 412-416.

Bertetti D, Poli A, Gullino ML, Garibaldi A. 2011 - First report of Phomopsis black rot caused by Phomopsis cucurbitae McKeen on cantaloupe (Cucumis melo L. var. cantalupensis Naudin) fruits commercialized in Italy. Protezione delle Colture 5, 32-34.

Cappelli C, Stravato VM, Carannante G, Parisella R. 2004 - First report of Cucumber Black Root Rot caused by Phomopsis sclerotioides in Italy. Plant Disease 88, 425-425. 
Carbone I, Kohn LM. 1999 - A method for designing primer sets for speciation studies in filamentous ascomycetes. Mycologia 91, 553-556.

Chen SF, Morgan DP, Hasey JK, Anderson K, Michailides TJ. 2014b - Phylogeny, morphology, distribution, and pathogenicity of Botryosphaeriaceae and Diaporthaceae from English walnut in California. Plant Disease 98, 636-652.

Chen SF, Morgan DP, Michailides TJ. 2014a - Botryosphaeriaceae and Diaporthaceae associated with panicle and shoot blight of pistachio in California, USA. Fungal Diversity 67, 157179.

Chomnunti P, Hongsanan S, Aguirre-Hudson B, Tian Q, Peršoh D, et al. 2014 - The sooty moulds. Fungal Diversity 66, 1-36.

Cinelli T, Mondello V, Marchi G, Burruano S, Alves A, et al. 2016 - First report of Diaporthe eres associated with cane blight of grapevine (Vitis vinifera) in Italy. Plant Disease 100, 532532.

Crous PW, Groenewald JZ, Shivas RG, Edwards J, Seifert KA, et al. 2011 - Fungal Planet description sheets, 69-91. Persoonia 26, 108-156.

Crous PW. 2005 - Impact of molecular phylogenetics on the taxonomy and diagnostics of fungi Bull OEPP/EPPO 35:47-51

Deidda A, Buffa F, Linaldeddu BT, Pinna C, Scanu B, et al. 2016 - Emerging pests and diseases threaten Eucalyptus camaldulensis plantations in Sardinia, Italy. IForest-Biogeosciences 9, 883-891.

Dissanayake AJ, Liu M, Zhang W, Chen Z, Udayanga D, et al. 2015 - Morphological and molecular characterization of Diaporthe species associated with grapevine trunk disease in China. Fungal Biology 119, 283-294.

Dissanayake AJ, Phillips AJL, Yan JY, Li XH, Hyde KD. 2017b - The current status of species in Diaporthe. Mycosphere (this volume).

Dissanayake AJ, Zhang W, Liu M, Hyde KD, Zhao WS, et al. 2017a - Diaporthe species associated with peach tree dieback in Hubei, China. Mycosphere 8, 533-549.

Frisullo S, Elshafie HS, Mang SM. 2015 - First report of two Phomopsis species on Olive trees in Italy. Journal of Plant Pathology 97, 401-401.

Gao YH, Liu F, Cai L. 2016 - Unravelling Diaporthe species associated with Camellia. Systematics and Biodiversity 14, 102-117.

Glass NL, Donaldson GC. 1995 - Development of primer sets designed for use with the PCR to amplify conserved genes from filamentous Ascomycetes. Applied Environment Microbiology 61, 1323-1330.

Golzar H, Tan YP, Shivas RG, Wang C. 2012 - First report of shoot blight of persimmon caused by Diaporthe neotheicola in Australia. Australasian Plant Disease Notes 7, 115-117.

Gomes RR, Glienke C, Videira SIR, Lombard L, Groenewald JZ, et al. 2013 - Diaporthe, a genus of endophytic, saprobic and plant pathogenic fungi. Persoonia 31, 1-41.

Gonthier P, Gennaro M, Nicolotti G. 2006 - Effects of water stress on the endophytic mycota of Quercus robur. Fungal Diversity 21, 69-80.

Guarnaccia V, Vitale A, Cirvilleri G, Aiello D, Susca A, et al. 2016 - Characterisation and pathogenicity of fungal species associated with branch cankers and stem-end rot of avocado in Italy. European Journal of Plant Pathology. 146, 963-976.

Hall T. 2006 - Bioedit. Department of Microbiology, North Carolina State University http://wwwmbioncsuedu/BioEdit/Bioedithtml.

Huang F, Udayanga D, Wang X, Hou X, Mei X, et al. 2015 - Endophytic Diaporthe associated with Citrus: A phylogenetic reassessment with seven new species from China. Fungal Biology 119, 331-347.

Hyde KD, Hongsanan S, Jeewon R, Bhat DJ, McKenzie EHC, et al. 2016 - Fungal diversity notes 367-492, taxonomic and phylogenetic contributions to fungal taxa. Fungal Diversity 80, 1270. 
Hyde KD, Nilsson RH, Alias SA, Ariyawansa HA, Blair JE, et al. 2014 - One stop shop: backbone trees for important phytopathogenic genera: I Fungal Diversity 67, 21-125.

Index Fungorum2017. http://www.indexfungorum.org/names/names.asp (accessed 10.06.17).

Jayasiri SC, Hyde KD, Abd-Elsalam KA, Abdel-Wahab MA, Ariyawansa HA, et al. 2015 - The faces of fungi database: fungal names linked with morphology, molecular and human attributes Fungal Diversity 74, 3-18.

Katoh K, Toh H. 2010 - Recent developments in the MAFFT multiple sequence alignment program Briefings in Bioinformatics 9, 286-298.

Liu JK, Hyde KD, Jones EBG, Ariyawansa HA, Bhat DJ, et al. 2015 - Fungal diversity notes 1110, taxonomic and phylogenetic contributions to fungal species. Fungal Diversity 72, $1-$ 197.

Lombard L, van Leeuwen GCM, Guarnaccia V, Polizzi G, van Rijswick, et al. 2014 - Diaporthe species associated with Vaccinium, with specific reference to Europe. Phytopathologia Mediterranea 53, 287-299.

Luongo L, Santori A, Riccioni L, Belisario A. 2011 - Phomopsis sp. associated with post-harvest fruit rot of kiwifruit in Italy. Journal of Plant Pathology. 93, 205-209.

Maharachchikumbura SSN, Hyde KD, Jones EBG, McKenzie EHC, Bhat DJ, et al. 2016 Families of Sordariomycetes. Fungal Diversity 79, 1-317.

Maharachchikumbura SSN, Hyde KD, Jones EBG, McKenzie EHC, Huang SK, et al. 2015 Towards a natural classification and backbone tree for Sordariomycetes. Fungal Diversity 72, 199-301.

Maresi G, Oliveira Longa CM, Turchetti T. 2013 - Brown rot on nuts of Castanea sativa Mill: an emerging disease and its causal agent. iForest - Biogeosciences and Forestry 6, 294-301.

Moricca S. 2002 - Phomopsis alnea, the cause of dieback of black alder in Italy. Plant Pathology $51,755-764$.

Mostert L, Kang JC, Crous PW, Denman S. 2001 - Phomopsis saccharata sp. nov., causing a canker and die-back disease of Protea repens in South Africa. Sydowia 53, 227-235.

Nicosia MGLD, Mosca S, Mercurio R, L. Schena. 2015 - Dieback of Pinus nigra Seedlings Caused by a Strain of Trichoderma viride. Plant Disease 99, 44-49.

Nylander, J.A.A. 2004. MrModeltest v2. Program distributed by the author Evolutionary Biology Centre, Uppsala University, Sweden.

Pecchia S, Mercatelli E, Vannacci G. 2004 - Intraspecific diversity within Diaporthe Helianthi: Evidence from rDNA intergenic spacer (IGS) sequence analysis. Mycopathologia 157, $317-$ 326.

Ragazzi A, Moricca S, Capretti P, Dellavalle I, Turco E. 2003 - Differences in composition of endophytic mycobiota in twigs and leaves of healthy and declining Quercus species in Italy. Forest pathology 33, 31-38.

Rayner R.W. 1970. A mycological colour chart Commonwealth Mycological Institute, Kew, UK.

Ronquist F, Huelsenbeck JP. 2003 - MrBayes 3: Bayesian phylogenetic inference under mixed models Bioinformatics 19, 1572-1574.

Santos JM, Correia VG, Phillips AJL. 2010 - Primers for mating-type diagnosis in Diaporthe and Phomopsis, their use in teleomorph induction in vitro and biological species definition. Fungal Biology 114, 255-270.

Santos JM, Phillips AJL. 2009 - Resolving the complex of Diaporthe (Phomopsis) species occurring on Foeniculum vulgare in Portugal. Fungal Diversity 34, 111-125.

Santos JM, Vrandecic K, Cosic J, Duvnjak T, Phillips AJL. 2011 - Resolving the Diaporthe species occurring on soybean in Croatia. Persoonia 27, 9-19.

Silvestro D. Michalak I. 2010 - RaxmlGUI: a graphical front-end for RAxML. Available from: http://sourceforgenet/projects/raxmlgui/ accessed 29 September 2016.

Swofford DL. 2003 - PAUP*: phylogenetic analysis using parsimony and other methods, version 4 Sinauer Associates, Sunderland, Massachusetts. 
Tan YP, Edwards J, Grice KRE, Shivas RG. 2013 - Molecular phylogenetic analysis reveals six new Diaporthe species from Australia. Fungal Divers 61, 251-260.

Thambugala KM, Daranagama DA, Phillips AJL, Bulgakov TS, Bhat DJ, et al. 2017 - Microfungi on Tamarix. Fungal Diversity 82, 239-306.

Thomidis T, Exadaktylou E, Chen S. 2013 - Diaporthe neotheicola, a new threat for kiwi fruit in Greece. Crop Protection 47, 35-40.

Thompson SM, Tan YP, Young AJ, Neate SM, Aitken EA, et al. 2011 - Stem cankers on sunflower (Helianthus annuus) in Australia reveal a complex of pathogenic Diaporthe (Phomopsis) species. Persoonia 27, 80-89.

Udayanga D, Castlebury LA, Rossman AY, Chukeatirote E, Hyde KD. 2014b - Insights into the genus Diaporthe, phylogenetic species delimitation in the $D$. eres species complex. Fungal Diversity 67, 203-229.

Udayanga D, Castlebury LA, Rossman AY, Chukeatirote E, Hyde KD. 2015 - The Diaporthe sojae species complex, Phylogenetic re-assessment of pathogens associated with soybean, cucurbits and other field crops. Fungal Biology 119, 383-407.

Udayanga D, Castlebury LA, Rossman AY, Hyde KD. 2014a - Species limits in Diaporthe, molecular re-assessment of $D$. citri, $D$. cytosporella, $D$. foeniculina and $D$. rudis. Persoonia $32,83-101$.

Udayanga D, Liu XZ, Crous PW, McKenzie EHC, Chukeatirote E, et al. 2012 - A multi-locus phylogenetic evaluation of Diaporthe (Phomopsis). Fungal Diversity 56, 157-171.

Udayanga D, Liu XZ, McKenzie EHC, Chukeatirote E, Bahkali AH, et al. 2011 - The genus Phomopsis, biology, applications, species concepts and names of common pathogens. Fungal Diversity 50, 189-225.

van Rensburg JCJ, Lamprecht SC, Groenewald JZ, Castlebury LA, Crous PW. 2006 Characterization of Phomopsis spp. associated with die-back of rooibos (Aspalathus linearis) in South Africa. Studies in Mycology 55, 65-74.

White TJ, Bruns T, Lee J, Taylor J. 1990 - Amplification and direct sequencing of fungal ribosomal RNA genes for phylogenetics In: Innis MA, Gelfand DH, Sninsky JJ, White TJ eds, PCR protocols: a guide to methods and applications: 315-322 Academic Press, San Diego, California, USA.

Williamson PM, Higher AS, Gams W, Sivasithamparam K, Cowling WA. 1994 - Diaporthe toxica sp. nov. the cause of lupinosis in sheep. Mycology Research 98, 1364-1368. 